\title{
Working
}

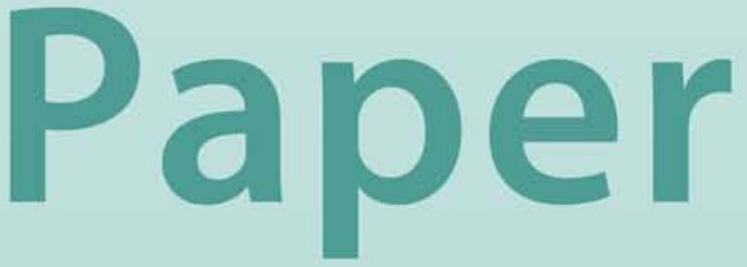




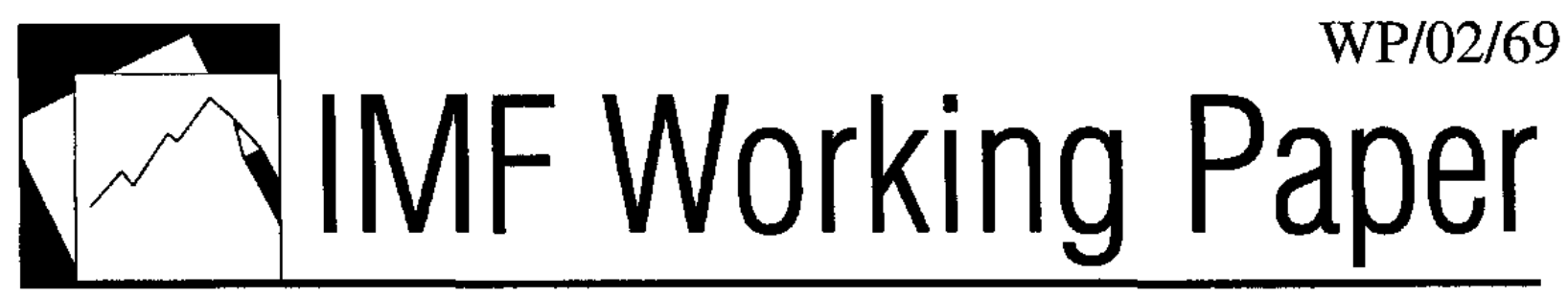

External Debt and Growth

Catherine Pattillo, Hélène Poirson, and Luca Ricci 


\title{
IMF Working Paper
}

\author{
Research Department
}

\section{External Debt and Growth}

\author{
Prepared by Catherine Pattillo, Hélène Poirson, and Luca Ricci ${ }^{1}$ \\ Authorized for distribution by Eduardo Borensztein
}

April 2002

\begin{abstract}
The views expressed in this Working Paper are those of the author(s) and do not necessarily represent those of the IMF or IMF policy. Working Papers describe research in progress by the author(s) and are published to elicit comments and to further debate.
\end{abstract}

This paper assesses the non linear impact of external debt on growth using a large panel data set of 93 developing countries over 1969-98. Results are generally robust across different econometric methodologies, regression specifications, and different debt indicators. For a country with average indebtedness, doubling the debt ratio would reduce annual per capita growth by between half and a full percentage point. The differential in per capita growth between countries with external indebtedness (in net present value) below 100 percent of exports and above 300 percent of exports seems to be in excess of 2 percent per annum. For countries that are to benefit from debt reduction under the current HIPC initiative, per capita growth might increase by 1 percentage point, unless constrained by other macroeconomic and structural economic distortions. Our findings also suggest that the average impact of debt becomes negative at about 160-170 percent of exports or $35-40$ percent of GDP. The marginal impact of debt starts being negative at about half of these values. High debt appears to reduce growth mainly by lowering the efficiency of investment rather than its volume.

JEL Classification Numbers:F21; F34; F43; O10; O40

Keywords: Growth, external debt, debt relief, HIPC initiative

Authors' E-Mail addresses: cpattillo@imf.org; hpoirson@imf.org; lricci@imf.org

\footnotetext{
${ }^{1}$ The authors would like to thank Bill Easterly for sharing his dataset on net present value of external debt; Eduardo Borensztein, Peter Clark, Daniel Cohen, Kenneth Kletzer, Paul Masson, Ashoka Mody, Sam Ouliaris, Eswar Prasad, Robert Powell, and Xavier Sala-i-Martin for useful discussions; and participants in the WIDER/UNU debt-relief conference (Helsinki, 2001) and IMF internal seminar; and Grace Juhn for excellent and invaluable research assistance.
} 


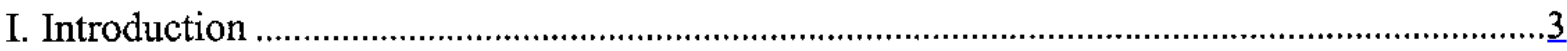

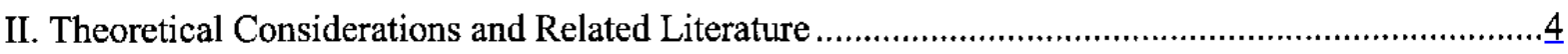

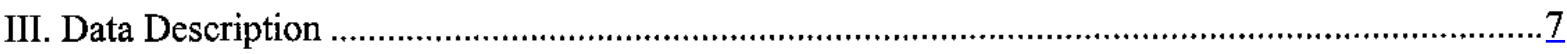

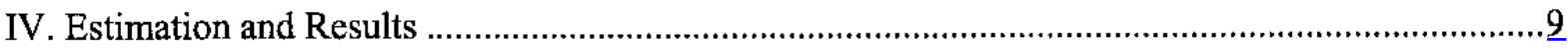

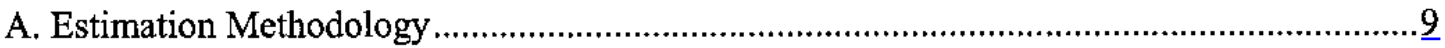

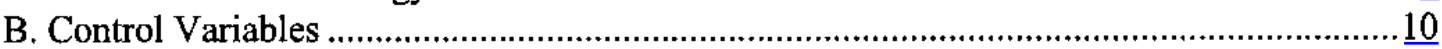

C. Specifications Investigating the Relation Between Debt and Growth .............................. 13

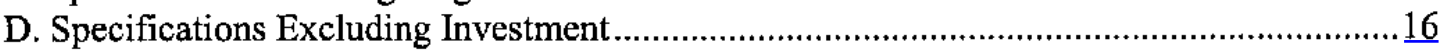

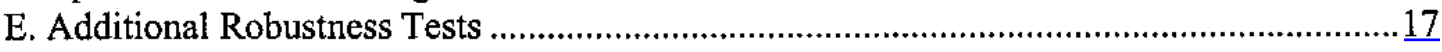

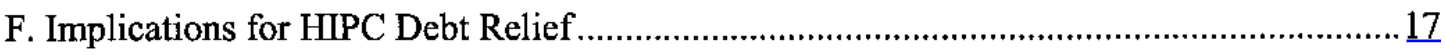

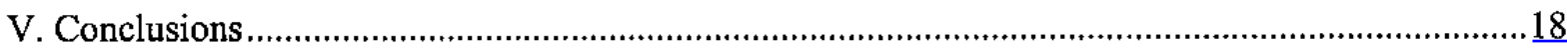

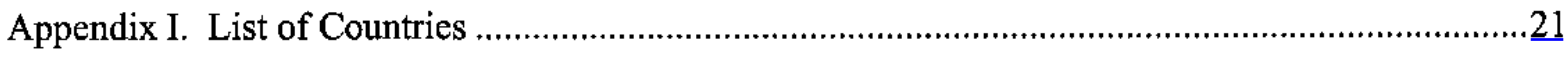

Tables:

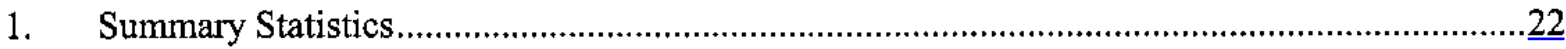

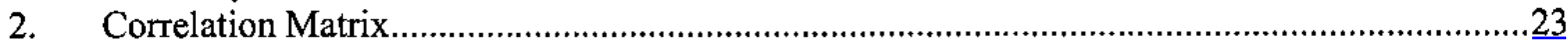

3. Debt/Exports: Linear and Quadratic Effects on Growth .....................................................24

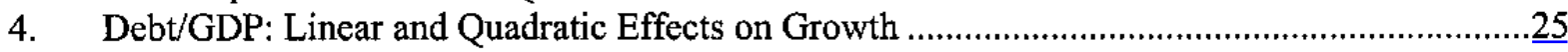

5. Net Present Value of Debt/Exports: Linear and Quadratic Effects on Growth...........................26

6. Net Present Value of Debt/GDP: Linear and Quadratic Effects on Growth ...............................27

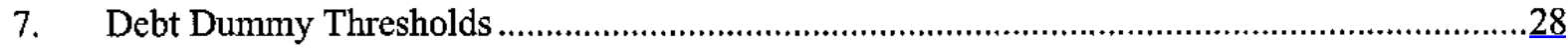

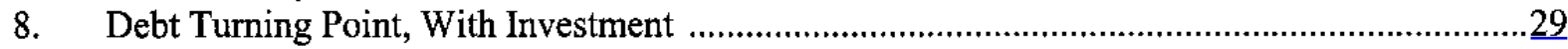

9. Effects on Doubling Debt on Growth, With Investment …..............................................

10. Effects of Doubling Debt on Growth, Without Investment ...................................................

11. Effects of Doubling Debt on Growth: panel decades, With Investment ....................................

12. Effects of Halving Debt on Growth (for HIPCs that reached the decision point)........................33

Figures:

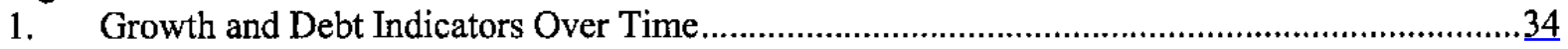

2. Growth and Debt Indicators Over Time, Without Outliers................................................... 35

3. Debt to Exports, Without Outliers, OLS, IV, FE

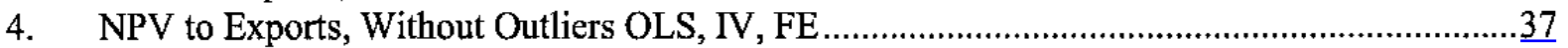

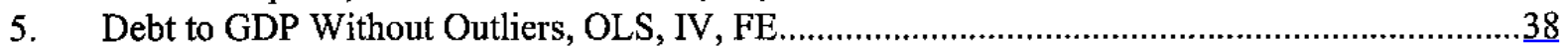

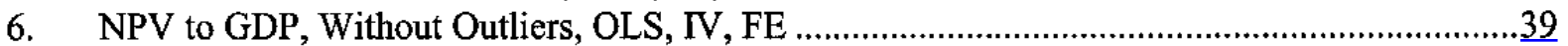

7. Debt to Exports, Without Outliers and Investment, OLS, IV, FE ...........................................

8. Debt to GDP, Without Outliers and Investment, OLS, IV, FE ............................................ 41

9. NPV to Exports, Without Outliers, and Investment, OLS, IV, FE ........................................

10. NPV to GDP, Without Outliers and Investment, OLS, IV, FE

11. Stylized Shape of the Non linear Relation Between Debt and Growth.....................................44

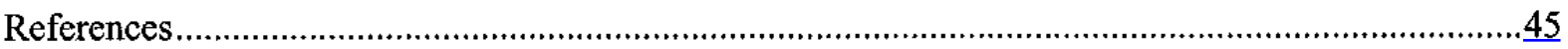




\section{INTRODUCTION}

In the second half of the 1990s, high external indebtedness of developing countries has received increased attention from policymakers and public opinion around the world, as one of the main factors contributing to limit the development of numerous poor countries. Most of these countries have received very large amounts of loans over the past decades, often at highly concessional interest rates. It has become clear, however, that repayment of the remaining net present value of the obligations would not only be virtually impossible but would also be likely to severely constrain economic performance of the debtor countries. International organizations as well as bilateral creditors have added to traditional debt relief mechanisms by implementing the Heavily Indebted Poor Countries (HIPC) Initiative, that provides conditional assistance to countries that meet specific policy and performance criteria. ${ }^{2}$ Movements such as Jubilee 2000; singers like Bono, Manu Chao, and Jovanotti; and some of the demonstrators in the recent protests against globalization illustrate the increased sensitivity to the debt issue among citizens in many countries.

Despite the importance of the issue, the large amount of attention from citizens, media, and policymakers, and the fervor of recent policy initiatives to reduce debt, there are very few studies that have addressed questions such as: (i) at what levels does external debt have a negative impact on economic performance, (ii) what is the extent of its impact on economic growth, and (iii) what are the channels through which the impact is likely to occur. Existing theoretical literature suggests that any nonlinear effects of debt on growth are likely to occur through the investment channel. However, one can also speculate that the effects may also operate through productivity, although this has not been formalized in existing theoretical models. Few empirical studies have focused on the relationship between debt and growth. There is some empirical evidence supporting the nonlinear effect of debt on growth but it is not robust, and limited in scope and methodology.

The objective of the paper is to contribute to the understanding of these issues, focusing on the first two, but also providing tentative answers to the third question. To this end, we make use of traditional (OLS, instrumental variables, and fixed effects) as well as recent econometric techniques (System GMM). In addition to simple linear regressions, we employ different specifications to investigate the non linearity of the relationship between debt and growth posited by the theoretical literature. These specifications include a model with debt dummies, a quadratic specification, and a spline function approach.

We identify a range of values (specific to the type of debt indicator) after which the impact of debt on growth becomes negative. For the net present value of debt to exports indicator, such a range is very close to the debt target ( 150 percent of exports) of the current HIPC Initiative. We also identify ranges of values for the optimal level of debt, i.e. the level after which the marginal impact of further debt accumulation becomes negative, which are, as expected,

${ }^{2}$ For a description, see http://www.imf.org/external/np/exr/facts/hipc.htm. 
much lower than the ranges in which the average impact of debt turns negative. Interestingly, for the average country in the sample, the effect of doubling debt is to reduce growth by half to a full percentage point, suggesting that the average country is already on the 'wrong' side of a hypothetical debt Laffer curve. Finally, and somewhat surprisingly, our results suggest that that most of the effect of debt on growth takes place through the quality of investment rather than just its level.

The remainder of the paper is divided in four sections: Section II provides a survey of the literature; Section III describes the data employed; Section IV outlines the estimation methods and reports the results; and Section V draws conclusions.

\section{Theoretical Considerations and Related Literature}

From the literature, what do we know about the effect of debt on growth and why would we expect the effect to be nonlinear? The issue is actually not well explored in theoretical models, but we can draw out the theories' implications for these questions. This section first discusses theory in which low, reasonable debt levels have a positive effect on growth, and second covers models where high accumulated debt stocks are likely to be associated with lower growth. Thirdly, we outline a few models that combine both these elements and imply that debt may have nonlinear effects on growth. Finally, we mention the two previous empirical studies related to nonlinear debt effects.

In various theoretical models, reasonable levels of current debt inflows are expected to have a positive effect on growth. In traditional neoclassical models, allowing for capital mobility, or the ability of a country to borrow and lend, increases transitional growth. There is an incentive for capital-scarce countries to borrow and invest since the marginal product of capital is above the world interest rate. Some endogenous growth models have similar implications. Eaton (1993), for example, extends the Uzawa-Lucas model and shows that an increase in the cost of foreign capital that lowers external borrowing leads to lower long-run growth. Models with perfect international capital mobility, however, are based on an unrealistic assumption and have empirical implications that are counterfactual (Barro and Sala-i-Martin, 1995; Barro, Mankiw, and Sala-i-Martin, 1995). A more realistic assumption is that countries may not be able to borrow freely because of the risk of debt repudiation, or moral hazard: if the borrowing country can hide its actions from the lender it may choose to consume or reinvest abroad some of the borrowed funds. (Gertler and Rogoff, 1990). In models with repudiation risk, such as Cohen (1991), low levels of debt are still associated with higher growth than in financial autarky.

But why do large levels of accumulated debt stocks lead to lower growth? First, we can point to models where political economy considerations lead to over borrowing and low growth, often accompanied by capital flight, if the costs of high taxes to service the debt are not internalized (Alesina and Tabellini, 1989, Tornell and Velasco, 1992). Second, and most well known, are debt overhang theories. These models argue that if there is some likelihood that in the future debt will be larger than the country's repayment ability, then expected debt 
service will be an increasing function of the country's output level. The returns from investing in the country therefore face a high marginal tax by the external creditors, and new domestic and foreign investment is discouraged. (Krugman, 1988; Sachs, 1989). Although the models do not analyze growth explicitly, the implication would be that large debt stocks would lower growth through the channel of reduced investment. However, many authors have argued that the debt overhang theory has broader implications, since any activity that requires incurring costs today for the sake of increased output in the future will be discouraged, as part of the proceeds will be taxed away by creditors (Corden, 1989). One implication may be that the government will have less incentive to undertake difficult reforms such as trade liberalization or fiscal adjustment. This means that the channel for the debt overhang's effect on growth may not only be through the volume of investment, but also through a poorer macroeconomic policy environment which is likely to affect the efficiency of investment. This environment can contribute to investment projects that are poorly designed and implemented and badly allocated, lowering the contribution of capital accumulation to growth.

Another strand of thinking in the debt overhang literature focuses on the fiscal aspects of the debt problem. Large accumulated debt stocks may be more likely to generate expectations that debt service will be financed with particularly distortionary types of taxation, such as the inflation tax, or with cuts in productive public investment. (Agénor and Montiel, 1996). Again, we infer that the transmission to growth is likely to be through the reduced efficiency of investment as well as lower investment volumes.

Thirdly, the literature has pointed out how debt may have negative effects on economic performance because of the uncertainty about what portion of the debt will actually be serviced with the countries own resources. It may not be clear at what terms debt will be rescheduled, whether there would be additional lending, what change in government policies the rescheduling will entail, etc. The investment under uncertainty literature has stressed that in highly uncertain environments, even if the fundamentals are improving, investors continue to exercise their option of waiting (Serven, 1997). As in other high uncertainty environments, we can conjecture that the investment that does take place in high debt environments will likely be in trading activities with quick returns, rather than long-term, high-risk, irreversible investment. This misallocation of investment in turn will lower the efficiency of overall capital accumulation, thus suggesting that high levels of debt and associated uncertainty might affect growth also via investment efficiency and productivity.

Thus far we have drawn on one type of theory that implies that reasonable levels of debt inflows would be expected to have a positive effect on growth, and another that stresses that large, accumulated debt stocks may be a hindrance to growth. The practical experience of the HIPCs appears consistent with these ideas. External borrowing was originally intended to finance domestic investment opportunities (as well as to smooth terms of trade shocks) but poor policies and continued borrowing in the face of negative external conditions meant that the investment, to the extent it actually took place, did not contribute much to growth. The continued borrowing and poor export performance of these countries led to very high accumulated debt stocks that have likely created uncertainty and debt overhang effects. 
There are also a few models that combine both these elements and imply that debt may have nonlinear effects on growth. In these models, the channel for these nonlinear growth effects of debt is through investment. We continue below our conjectures that these effects may also operate through productivity. Cohen (Cohen and Sachs, 1986; Cohen, 1991, 1992) presents an endogenous growth style model where capital accumulation is the sole force driving growth. Countries' access to international financial markets is limited because of the risk of debt repudiation. Growth is high in the early stages as the country borrows and invests. Then later, growth falls to a lower level, but one that Cohen stresses is still higher than it would be if there were no international borrowing and lending (financial autarky). The stage of repaying the countries' debts does not crowd out investment, but rather encourages it because lenders are more patient and value growth more than the debtor country itself. This result, however, depends on the ability of lenders to implement an optimal rescheduling policy. If they are not able to commit to this policy over the life of the lending relationship, a debt overhang scenario will occur and investment and growth in the later stages will be even lower than in financial autarky.

Another relevant model is Calvo (1998), which links the debt and growth problem to capital flight. In a relatively simple model, high debt is associated with low growth since a higher distortionary tax burden on capital is required to service the debt, leading to a lower rate of return on capital, lower investment and growth. Low debt regimes have high growth for the opposite reasons. In intermediate ranges of debt, however, the effect on growth is indeterminate. The mechanism behind the possibility of multiple equilibria is a reverse causation from growth to the tax burden: if the economy grows more slowly, then the tax rate necessary to obtain enough resources to repay a given debt will have to be higher, and viceversa. The likely empirical implications of this type of model are nonlinear effects of debt on growth in the cross-sectional dimension of the data.

Finally, although the debt overhang theory has not explicitly traced the effect to growth, it may be possible to extend these types of models and translate a debt Laffer curve into a Laffer curve for the effect of debt on growth. The debt Laffer curve shows that along the left, or "good" side of the curve, increases in the face value of debt service are associated with increases in debt repayment, while increases in the face value lower expected repayment on the right or "wrong" side of the curve. Since the peak of the curve is the point where large debt stocks begin acting as a steep marginal tax on investment, policy reforms or other activities that require up-front costs in exchange for future benefits, this may relate to the point at which debt begins to have a negative marginal impact on growth. Again, to the extent that the high debt serves as a tax hindering policy reforms, the resulting distorted macroeconomic environment is likely to contribute to lower investment efficiency and productivity.

Turning to empirics, the empirical growth literature has grown extremely large, and several papers have found some negative effects of debt on growth. It is important, however, to isolate the channel through which debt affects growth. Most existing studies do not attempt to distinguish the crowding out effect from the debt overhang effect. To isolate the debt overhang effect (which can be captured with a variable representing the burden of future debt 
service, such as the debt stock), it is important to also control for potential crowding out, (proxied by a contemporaneous debt service ratio). In addition, previous studies use the face value of debt stocks, rather than the net present value of debt. The latter reflects the degree of concessionality of loans and thus more accurately measures the expected burden of future debt service across countries.

Two existing studies specifically relate to the nonlinear effects of debt. Cohen (1997) does not use the debt stock directly in a growth regression, but rather finds that a variable representing the predicted risk of a debt rescheduling (or debt crisis) significantly lowers growth. Such a probability of rescheduling depends positively on external indebtedness. He uses this method to find debt ratios above which the probability of rescheduling becomes excessive: debt to GDP of 50 percent, and debt to exports of 200 percent.

Elbadawi et al. (1997) is the only empirical study we are aware of that directly considers nonlinear effects of debt on growth. They present fixed and random effects panel estimates of a growth regression in which debt to GDP enters both in linear and quadratic form. The results imply growth maximizing debt to GDP ratio of 97 percent, which is quite high considering that the average debt to GDP ratio in our sample is 70 percent. As discussed below, this study finds significantly lower growth maximizing debt thresholds.

\section{Data Description}

The analysis uses panel regressions for 93 developing countries spanning Sub-Saharan Africa, Asia, Latin America, and the Middle East over the period 1969-98. ${ }^{3}$ The data are from various sources. Real Purchasing Power Parity GDP is from the WEO database of the IMF, as data for several countries and for the latter half of the last decade are not available in the Summers-Heston dataset. Population, secondary education, and investment to GDP are from the World Bank databases. Nominal debt to exports and to GDP is from the Global Development Finance dataset (World Bank), complemented with WEO data. Net present values of debt data have been kindly provided by William Easterly (see Easterly, 2000). Debt service to exports is from the Global Development Finance dataset (World Bank). The terms of trade, fiscal balance to GDP (central government), and openness as ratio of GDP are from the WEO database. Descriptive statistics for all variables are provided in Table 1.

We calculate three-year averages, to net out the effects of short run fluctuations, while maintaining the ability to utilize the time series dimension of the data. The latter feature of the data compilation is quite important, given that understanding how debt affects growth over time (the within-country variability of the panel data) is at least as important as understanding how countries with different levels of debt experienced different growth

\footnotetext{
${ }^{3}$ The sample is reduced to 88 countries when net present value of debt indicators are used.
} 
patterns (the between-country variability of the panel data). Our complete data set consists of 630 observations for 93 countries over the period 1969-98 ( 88 countries when using the net present value indicator of debt). ${ }^{4}$ We also use ten-year averages to check the robustness of our findings, as business cycle effects may not be entirely netted out with only three-year averages.

As a first step in exploring the bivariate relationship between growth and debt, Figures 1 and 2 plot the evolutions of the average growth and debt indicators over time. The averages were computed for all countries ${ }^{5}$ and for a reduced sample excluding outliers ( 89 countries for the face value indicator sample and 85 countries for the net present value indicator sample). ${ }^{6}$ The figures show that debt ratios have peaked in the late 1980s, and have since declined, in part owing to traditional and new debt relief mechanisms. Net present value of debt begins to be lower than nominal debt towards the early 1980 s, due to the growing concessional element of many lending arrangements, especially to the poorest and most indebted countries. Growth appears to be negatively correlated with debt, as it drops during the build-up of debt at the beginning of the sample and it rises during the reduction of debt at the end of the sample. The peculiar pattern of the debt service variable over time raises some questions about the quality of the data.

The correlation matrix presented in Table 2 confirms the time-series evidence in Figures 1 and 2, suggesting a negative relationship between debt and growth also in the cross-section dimension. ${ }^{7}$ Growth is negatively and significantly correlated with all the external debt burden indicators. Correlations between the different debt indicators are positive and significant, as expected, and relatively high although always less than 85 percent. The debt indicator that is most highly correlated with growth is debt to exports while the indicator with the lowest correlation is debt service to exports (the correlation between growth and net present value of debt to income is also relatively low, albeit higher than between growth and debt service).

\footnotetext{
${ }^{4}$ However, the presence of lagged income in the estimation reduces the actual estimation sample to 9 periods, or 1972-98.

${ }^{5}$ Two observations for Yemen, an extreme outlier with respect to the debt-exports variable, with ratios reaching 20000 percent, were dropped for the computation of sample means shown in Figure 1.

${ }^{6}$ For each variable, outliers are defined as observations that deviate from the mean by more than five times the standard deviation.

${ }^{7}$ The cross-section variability dominates the correlations shown in Table 2 as the number of countries is much larger than the number of time-series observations.
} 


\section{ESTIMATION AND RESULTS}

Part of the above noted correlation between debt and growth may be spurious, reflecting the effects of third factors (not only traditional growth determinants, but also, as mentioned earlier, the presence of unobserved country effects). This section checks whether a debtgrowth relationship appears also in multivariate regression analysis. In other words, it seeks to determine whether the debt-growth correlation is robust to including a set of conditioning variables, including the usual determinants of growth (investment, human capital, policy variables) and in certain specifications, time and country effects. The analysis also checks for nonlinearity of the debt-growth relationship, posited by theory, and addresses the issue of causality by using estimation methods that account for the endogeneity of some of the explanatory variables (including debt).

\section{A. Estimation Methodology}

In order to investigate the impact of external debt on growth we augment a standard growth specification based on conditional convergence by adding several debt variables. ${ }^{8}$ The dynamic panel data model we estimate therefore has per capita growth as the dependent variable, and on the right-hand side includes, as control variables, lagged income per capita, the investment rate, the secondary school enrollment rate, the population growth rate (all in $\log$ ), a number of other variables to control for differences in total factor productivity (openness, fiscal balance), and exogenous shocks (terms of trade growth). To the extent that we control for investment, our results are biased toward finding a smaller effect of debt on growth. As suggested by theory, in fact, part of the effect of debt on growth may occur indirectly through the investment channel rather than directly through the efficiency and productivity channel. We investigate this further using an alternate specification that excludes investment.

Most of the dynamic panel specifications are estimated using: (a) simple OLS;

(b) instrumental variables - henceforth IV-to correct for endogeneity (the schooling, investment, fiscal balance, openness, and debt variables are instrumented to account for a potential simultaneity bias; the estimation method is two-stage least squares, using as instruments the lagged values of the endogenous regressors and the contemporaneous values of the other regressors); (c) fixed effects to allow countries to have different intercepts (that may be correlated with the regressors); and (d) system GMM to correct for endogeneity and for the bias introduced by the lagged income variable in the presence of fixed effects.

The first two methods do not account for the presence of country effects, and thus results may be affected by an omitted variables bias. Therefore we also estimate regressions with fixed effects (third and fourth methods). In the presence of fixed effects however, the results with traditional panel data estimation (fixed effects) are biased by the presence of the lagged

\footnotetext{
${ }^{8}$ See Mankiw, Romer, and Weil (1992), henceforth MRW.
} 
income variable among the regressors. ${ }^{9}$ Recently developed methods such as differencedGMM and system-GMM yield unbiased estimates, and simultaneously address the endogeneity issue for some of the explanatory variables (Blundell and Bond, 1998). Finally, unlike fixed effects or differenced-GMM, the system-GMM method does not entirely wipe out the cross-country dimension of the data by first-differencing (diff-GMM) or taking differences with respect to country means (fixed effects). Instead, cross-country information is used by jointly estimating the equation in first-difference and in levels, with firstdifferences instrumented by lagged levels of the dependent and independent variables - as in the diff-GMM method-and levels instrumented by first- differences of the regressors. These additional instruments are valid as long as they are uncorrelated with the fixed effects and exploiting these additional restrictions means that the sys-GMM estimator is more efficient than the diff-GMM one.

To ensure that our results are not driven by time specific effects or the presence of outliers, we estimate most regressions with and without time dummies as well as with the full sample and with a reduced sample where outliers are eliminated. ${ }^{10}$ For parsimony, some non linear specifications and the system GMM are run only with the best case, i.e. with time dummies and excluding outliers. Broader robustness analysis is then provided through the use of 10-year panel data regressions to eliminate possible remaining cyclical effects. Estimating the same specifications excluding the investment variable allows us to test whether the capital accumulation is the channel through which debt impacts growth.

\section{B. Control Variables}

The set of control variables encompasses: initial income per capita, population growth rate, ${ }^{11}$ investment rates, school enrollment rates (all in log terms), terms of trade growth, fiscal balance to GDP, and openness (exports plus imports over GDP). In the conditional convergence framework, initial income is expected to have a negative coefficient, reflecting the convergence effect, the coefficient on population growth is also expected to be negative, while the coefficients on investment and schooling rates are predicted to be positive. Investment and education reflect the positive impact of physical and human capital accumulation respectively. The terms of trade growth reflects external shocks, and is expected to have a positive coefficient. The fiscal variable should have a positive coefficient,

\footnotetext{
${ }^{9}$ The presence of the fixed effects introduces a correlation between the lagged income variable and the residual, which biases the results. In particular, the coefficient on the lagged income variable is negatively biased.

${ }^{10}$ For each variable, outliers are defined as observations that deviate from the mean by more than five times the standard deviation.

11 Augmented by the rate of technical progress ( 2 percent) and by the rate of depreciation (3 percent), as in Mankiw, Romer, and Weil (1992).
} 
reflecting the positive effects of macroeconomic sustainability and stability on productivity. Trade openness is also posited to boost productivity through transfers of knowledge and efficiency gains.

Table 2 shows unconditional correlations that confirm most of the effects of different growth determinants predicted by theory. Bivariate correlations between growth and investment, and growth and fiscal balance are the highest and both have the expected sign (positive).

Schooling, openness, and terms of trade growth are positively and significantly correlated with growth, while population growth is negatively and significantly correlated. The unconditional correlation of growth and initial income per capita is not significant, a result common in the growth literature: the data do not lend support to the notion of unconditional convergence. $^{12}$

Tables 3 to 6 show the estimated coefficients in a growth equation with this set of control variables. They are consistent with those normally presented in the growth literature. All have the expected signs and are generally significant at the 10 percent level at a minimum, with the two exceptions of openness which is significant only in regressions with fixed effects and schooling which is insignificant in all the fixed-effects results. Note also that:

- The coefficient of initial GDP is significantly negative in all regressions, confirming the conditional convergence hypothesis, a standard result in the empirical growth literature. The implied convergence rate is somewhat higher than the usual estimates of 2 percent, in the order of 3.5 percent per year based on our preferred system-GMM results. $^{13}$

- Investment is highly significant in all the regressions, even though it is treated as endogenous in the IV levels estimation and in the system-GMM specification. In the IV and system-GMM estimations, the coefficient on investment is similar to the estimates provided by MRW (2.1-2.2) and Cohen (1997) (1.4-1.9), while it tends to be higher in the OLS and fixed-effects results, possibly reflecting an upward bias due to the partial endogeneity of investment.

- Schooling is highly significant, except in the fixed effects regressions. A number of studies have similarly found that the partial correlation between schooling and growth is not robust (e.g. Islam, 1995, and Pritchett, 1996). The result may be due to the limited time-series variability of schooling, when most of the relationship between

\footnotetext{
${ }^{12}$ However, the notion of conditional convergence is supported by the empirical literature, including in the results presented here.

${ }^{13}$ The OLS and IV results which omit country effects tend to yield a convergence coefficient which is biased upward, while the fixed effects estimate of the convergence rate is biased downward (Hoeffler, 1999).
} 
schooling and growth arises from cross-country variability. This interpretation is supported by the fact that schooling is significant and positive in all regressions that also make use of the cross-country variation. In particular, schooling remains highly significant when it is treated as endogenous (IV) and when both endogeneity and the fixed effect-bias are taken into account (system-GMM).

- The coefficient on population growth is negative in all regressions and significant in all but the fixed effects estimation.

- The coefficient of fiscal balance is significantly positive in all regressions. The OLS, fixed effects, and IV-levels results, are close to Easterly (1997) who finds a range of $0.08-0.18$ for the fiscal balance coefficient. Interestingly, the impact of fiscal balance is much higher in the system-GMM results, in the order of one-third, even though in that specification fiscal balance is treated as endogenous.

- The growth in terms of trade has a significant, positive impact on growth, consistent with the estimates of Barro and Sala-i-Martin (1998), which range from 0.03 to 0.15. Our estimates are consistently in the low side of this range in all specifications $(0.02-0.03)$.

- Openness is positive and significant in most of the fixed effects and some of the system-GMM specifications. It is insignificant however when country effects are not included (OLS and IV), a result consistent with that of other studies (Cohen, 1997). Cohen (1997) provides some interpretation of this result, showing that the relationship between growth and openness (adjusted by size to proxy for the degree of "true openness") is positive and significant only in those countries that have liberalized trade. The inclusion of country effects can be seen as capturing both size and harmful effects of distortions on trade, allowing the relationship between openness and true trade openness to emerge.

The set of control variables is complemented with the ratio of debt service to exports, which is expected to have a negative coefficient, as high debt servicing could prevent a country from devoting resources to productive activities (crowding-out hypothesis). However, our focus on this variable is limited as it does not measure the actual payments, but rather the scheduled ones. ${ }^{14}$ Notably, this variable is never significant (even in the regressions which do not include investment), although it generally does have the expected negative sign. ${ }^{15}$

We have quantified the impact of the different control variables on growth by calculating the effect of a one-standard deviation increase, based on the regression estimates in Tables 3 to 6

\footnotetext{
${ }^{14}$ Data for actual payments are not available for a large sample of countries.

${ }^{15}$ Except in regressions where the point estimate is very close to zero.
} 
(Appendix 2). The results suggest that the variables which have the largest impact on per capita growth are catching-up (lagged income), schooling, investment, and fiscal balance, while openness and terms of trade have a lesser impact. For example, when fiscal balance goes up by 5 percent (the standard deviation of this variable in the sample), per capita growth increases by about 1 percent, ranging from 0.5 to 1.5 percent depending on the specification and estimation method used.

\section{Specifications Investigating the Relation Between Debt and Growth}

\section{Linear specification}

A first specification assumes a linear relationship between external debt and growth,

$$
y_{i t}=\alpha_{(i t)}+\beta X_{i t}+\gamma D_{i t}+\varepsilon_{i t}
$$

where $y_{i t}$ represents per capita growth, $X_{i t}$ the control variables, and $D_{i t}$ the debt indicator. Tables 3 to 6 show that for each of the four debt variables and the four methodologies, the coefficient is almost always negatively signed and is significant in about half of the cases. All debt indicators are significant in the fixed effects specification, debt to exports (in both nominal and net present value terms) is also significant in the system-GMM specification, and debt to income is significant also in the OLS specification.

As we have noted, there are theoretical reasons suggesting that such a linear specification might be inadequate to identify the impact of debt on growth, as the relation is likely to be non linear. This may explain the lack of robustness of linear specification results. In fact, the effect of debt could be positive at low levels of debt as the reduction of liquidity constraints in the economy might be associated with the growth-inducing effects of capital inflows. The effect of debt could however become negative when external indebtedness become excessive, as the debt overhang might be growth-retarding. We believe the linear estimation would underestimate the impact by failing to capture the non linear relation between debt and growth and therefore imposing a flatter slope even when managing to capture a negative coefficient.

\section{Non linear specifications}

Ideally a non linear specification would allow us to:

- Identify the level of debt at which the overall—or average--impact of debt on growth becomes negative, in the sense that an increase in debt would lead to growth that is lower than in the case of no-indebtedness. If we could plot growth against debt (once all other growth determinants, including a constant term, were controlled for), this level would correspond to the intercept of the function on the horizontal axis (see point B in Figure 11, which provides a visual summary of the nonlinear relationship between debt and growth). 
- Identify the level of debt at which the marginal impact of debt on growth becomes negative, in the sense that an increase in debt yields a negative marginal contribution to growth, independently of whether growth is higher with respect to the case of noindebtedness. Again, if we could plot growth against debt, this level would correspond to the peak or turning point of the nonlinear function (see point $\mathrm{A}$ in Figure 11).

- Quantify the impact of debt on growth in each of the cases above. In a hypothetical plot of growth against debt, this would correspond to the slope of the function.

The level of debt at which the overall impact of debt on growth becomes negative.

In order to address the first issue, we include a set of debt dummies in the regressions:

$$
y_{i t}=\alpha_{(i t)}+\beta X_{i t}+\gamma_{2} d_{2}+\gamma_{3} d_{3}+\gamma_{4} d_{4}+\gamma_{5} d_{5}+\varepsilon_{i t}
$$

where $d_{2}$ to $d_{5}$ are dummies representing inclusion in the second to the fifth quintile of debt (where the quintiles are constructed separately for each debt indicator after ranking all debt observations). Table 7 presents the quintile thresholds for each of the four debt variables. As one can see from the Table, the thresholds are evenly spaced, hence building dummies on the basis of absolute thresholds would yield very similar results to our approach of deriving relative thresholds from ranking exercises. Our methodology, however, avoids the arbitrariness of choosing thresholds. Given the presence of a constant, the first dummy is omitted, implying that the coefficients of each dummy indicates the effect of that range (quintile) of indebtedness with respect to zero or low debt (first quintile). The logarithmic specification is not ideal for this issue, as it imposes a functional form where the curvature is minimal at high levels of debt, so that it tends to identify a very high level of debt at which the overall impact of debt on growth becomes negative.

Figures 3 to 6 suggests that debt levels belonging to the third, fourth, or fifth debt dummy tend to significantly reduce growth. This suggests that debt levels beyond 160-170 percent of exports, or 35-40 percent of income, might be detrimental to growth (for example, point B in Figure 11). The thresholds are similar when debt is measured in nominal or net present value terms, suggesting that concessional lending flows mostly to countries that already have excessive levels of indebtedness. The results also indicate that the per capita growth differential between the countries in the highest and lowest quintile of indebtedness is, on average, in excess of 2 percent (note that 75 percent of the observations in the fifth dummyi.e. with NPV of debt to export ratios in excess of 300 percent-belong to HIPC countries).

\section{The level of debt at which the marginal impact of debt on growth becomes negative}

To address the second issue we employ a quadratic and a spline specification.

The following quadratic specification 


$$
y_{i t}=\alpha_{(i t)}+\beta X_{i t}+\gamma D_{i t}+\delta D_{i t}^{2}+\varepsilon_{i t}
$$

would support a debt and growth Laffer curve relationship if the coefficient of debt is positive and the coefficient of debt squared is negative, which is the case in most regressions in Tables 3 to 6 . The peak of the quadratic function identifies the level of debt at which the marginal impact of debt on growth becomes negative.

The following spline function

$$
y_{i t}=\alpha_{(i t)}+\beta X_{i t}+\gamma D_{i t}+\chi\left(D_{i t}-D_{i t}^{*}\right) Z+\varepsilon_{i t},
$$

where $D^{*}$ represents the debt threshold and $Z$ is a dummy equal to 1 if debt is above $D^{*}$ (and 0 otherwise), allows us to estimate a regression where the impact of debt on growth can have a structural break, in the sense that the impact is different below and above the threshold. In this case, one can determine the best debt threshold $\mathrm{D}^{*}$ by estimating regressions for different thresholds and evaluating which regression produces the highest R-squared. ${ }^{16}{ }^{17} \mathrm{The}$ threshold for the marginal impact of debt as identified with these two methods is supposedly the growth-maximizing level of external debt. It should be lower, by construction, than the threshold for negative average impact of debt based on the debt dummies approach.

Table 8 presents the levels of debt at which the marginal impact of debt on growth becomes negative, for each of the four variables, for both the quadratic and spline specification and with all the methodologies suggested above. In general, it appears that such turning points vary between 30 and 115 percent of exports, and 5 and 90 percent of GDP; for the net present value indicator, the turning point varies between 30 and 295 percent of exports, and 5 and 50 percent of GDP. The high variability of the results suggests that it is very difficult to identify precisely the growth maximizing level of debt. When considering the average of the significant coefficients, however, we estimate that such thresholds correspond approximately to half of those for the overall negative impact of debt on growth.

The negative impact of debt on growth beyond the threshold, in the spline specifications is much larger than the impact estimated from the linear regressions. ${ }^{18}$ This is consistent with a nonlinear relationship between debt and growth. (In this case imposing a linear specification would misleadingly yield a lower slope coefficient). While the coefficient estimate of debt

${ }^{16}$ The debt dummies may not perform as well as the quadratic and spline methodologies in addressing the issue of the marginal impact of debt on growth, as it would be necessary to divide the sample into very small debt groups dummies, which would be characterized by high variability of the data.

${ }^{17}$ See Sarel (1996) for an application to the nonlinear effect of inflation on growth.

${ }^{18}$ The thresholds are identified in Table 8. 
ranges from -0.4 to -1.2 in Tables 3-6 (linear regressions), the coefficient of debt beyond the threshold (spline regressions) ranges from -0.7 to -2.6 , which is about twice as large. ${ }^{19}$

\section{The impact of debt on growth}

To address the third issue we employ a quadratic and a spline specification, as well as providing the estimate from the linear specification. Table 9 summarizes the implication of the regression analysis for the impact of doubling debt on growth. For the quadratic specification, the figures presented indicate the impact evaluated at the average level of debt. For the spline specification, the figures indicate the impact evaluated at the spline threshold, i.e. at the level of debt at which the marginal impact on debt becomes negative. For the linear specification, the estimates indicate the impact for any level of debt.

It is surprising to notice that the estimates are very similar across all debt ratio indicators, specifications, and methodologies. For the average country in the regression, doubling the extent of indebtedness generally implies a reduction of growth of half to a full percentage point. $^{20}$

\section{Specifications Excluding Investment}

The previous regression analysis identifies a significantly negative effect of debt on growth (particularly above certain thresholds), when investment is included in the growth regression. This seems to support the hypothesis that the channel of influence for debt's effect on growth may be also through changes in the efficiency of investment, either because the same nominal expenditure in investment is not allocated to the most productive activities, or because there is limited innovation. We now test whether the negative debt effects are stronger if we exclude investment from the regression. This exercise is aimed at providing an indirect assessment of whether the effect of debt on growth may be stronger through the efficiency or the volume of investment.

Figures 7 to 10 and Table 10 replicate the information provided by Figures 3 to 6 and Table 9. Quite surprisingly it appears that the impact of debt on growth is only slightly stronger when we eliminate investment from the regressions, suggesting that the main channel through which large debt negatively influences growth is lower quality of investment (and maybe lower total factor productivity) rather than the level of investment per se.

\footnotetext{
${ }^{19}$ To save space, the coefficient estimates for the spline regressions are not reported, but are available from the authors upon request.

${ }^{20}$ The average log of debt was approximately (once exponetiated): Debt/exports: 182 percent; Debt/GDP: 46 percent; NPV of Debt/exports: 170\%1 NPV of Debt/GDP: 36 percent.
} 


\section{E. Additional Robustness Tests}

The robustness of the results can already be assessed by comparing the numerous specifications and methodologies described so far. However, one may be concerned that the use of 3-year averages might influence the results, if it captures more business cycle than long run effects. We therefore estimate the same regressions for a dynamic panel of 10-year average data. Table 11 suggests that the results are very similar. As with the 3-year average data, doubling the level of indebtedness generally implies a reduction of per capita growth by half to a full percentage point.

\section{F. Implications for HIPC Debt Relief}

Our results can be used to shed some light on the potential growth impact of debt relief for the average HIPC country. Official documents show that the net present value of debt in the year 2000 was on average about 300 percent of exports and 80 percent of GDP. ${ }^{21}$ As the objective of the initiative is to eventually reduce the net present value of debt of HIPC countries to 150 percent of exports, we can evaluate the effect of halving the debt from its 2000 level using each of the four debt indicators. This exercise then also assumes that net present value of debt to GDP and the two ratios of nominal debt to exports and GDP would be halved by HIPC debt relief.

The impact of halving the debt based on the linear models and spline functions would be identical in size (but with the opposite sign of course) to the previous doubling debt exercise, and is therefore reflected in the absolute value of the figures shown in Tables $9-11$. $^{22}$ Table 12 summarizes the results for the quadratic estimation, where it is also necessary to consider the starting point (average current level of debt of the HIPC countries). In general, halving the debt from the levels borne by HIPC countries in 2000 is estimated to raise per capita growth by about 1 percent. This appears to hold whether or not investment is controlled for, suggesting that most of the effect on growth is through increases in investment quality or effeciency.

${ }^{21}$ International Development Association and International Monetary Fund (2001), Annex table 3a, column 1 and Annex table 5, column 1. These figures are actually likely to underestimate the extent of indebtedness, as they are calculated only for countries that reached a decision point.

${ }^{22}$ Given the starting levels of indebtedness of HIPC countries that reached decision points, halving indebtedness ratios would leave them at an indebtedness level close to but still beyond the growth-optimizing debt threshold identified in the spline regressions. The impact of reducing or increasing indebtedness is the same in that specification (but with the opposite sign) as long as the countries level of indebtedness remains on the same side of the threshold. 
However, these results identified for reductions of debt to export ratios from 300 to 150 percent may not automatically apply to the case of the HIPCs, given the standard results of the second best theory, and the fact that the regression holds for the average country in the sample. For HIPCs, the disincentive to invest and the skewness in the allocation of resources towards economic activities with short run horizons might not improve when debt is reduced, as other macroeconomic and structural distortions as well as political factors might still be binding. ${ }^{23}$ It should be noted, nonetheless, that the policy conditionality associated with the HIPC debt relief will contribute to bringing the macroeconomic situation of the HIPC countries closer to that of the average country in the sample. Still, further study would be necessary to investigate the case of the HIPC countries in particular.

Other arguments that are skeptical of a potential positive growth effect from a debt reduction in the HIPC cases are less convincing. First, it could be argued that a positive effect on growth is unlikely as countries will still continue to have a substantial debt service burden. It should be noted, though, that the HIPC countries generally receive grants and official financing which reduce the problem of current negative resource transfers (which would otherwise limit the amount of economic resources that can be currently devoted to investment activities). It is true, however, that the uncertainty about the extent of future grants and official aid could still contribute to distortions in the incentives to invest and to allocate resource efficiently. Second, one may think that the potential growth benefit is likely to be small as the debt reduction under the HIPC initiative might have been already anticipated by the investors. (That is, that HIPCs have not had a debt overhang problem recently as it was not expected that they would repay their debts). However, this point relates to when the growth effect may take place, and not whether it may take place. If one were to believe that the HIPC debt reduction from 300 to 150 percent of exports is already fully anticipated by investors (a questionable assumption), then investment incentives might have already improved and might be contributing to better growth prospects.

\section{Conclusions}

This paper attempts to provide a thorough analytic answer to an important economic issue that is demanding increasing attention and efforts from policymakers, lending institutions, international organizations, and citizens around the globe: the impact of debt (and of debt reduction) on growth.

Toward this aim, we begin with a standard growth framework and add various indicators of debt; in nominal and in net present value terms, measured both as a ratio to exports and to GDP. We use several econometric specifications (quadratic debt terms, a model with debt dummies, a spline function, in addition to a simple linear specification) to investigate the

${ }^{23}$ See for example Easterly (2001) for a discussion of why debt forgiveness may not improve economic performance if the domestic incentive structure is poor. 
nonlinearity of the relation between debt and growth. The paper also employs several different methodologies (OLS, instrumental variables, fixed effects, and system-GMM) to show how results differ when econometric issues such as endogeneity, country specific effects, and accounting for endogeneity while eliminating fixed effect-biases in dynamic panels are taken into account. We use data for 93 developing countries from the period from 1969 to 1998 and construct 3-year averages to retain information on the time dimension of the change in debt. However, the results are checked by using panel regressions with 10-year averages to eliminate any residual business cycle effects. An additional robustness test is provided by estimating regressions which eliminate outliers and include time dummies.

The main results of the paper are interesting and intuitive.

- Debt appears to have a nonlinear effect on growth, which is depicted in a stylized fashion in Figure 11. Given the large differences of experiences across countries and over time, our results do not allow us to precisely estimate such a nonlinear relation, and the following statements-as well as Figure 11 -should be considered as suggestive.

- The average impact of debt on per capita growth appears to become negative for debt levels above 160-170 percent of exports and 35-40 percent of GDP.

- As suggested by the quadratic and spline specifications, the marginal impact of debt becomes negative at much lower debt levels, about half of the above ones, while the effect on growth seems to be positive at even lower levels. However, it is very difficult to accurately estimate the turning point because of the limited variation in the data between the growth experiences of countries with low indebtedness and those with low-to-moderate indebtedness.

- Regarding the quantitative impact of debt on growth, for the average country in the sample, the estimates are surprisingly consistent over the various estimation methodologies, specifications, and debt indicators employed. The results suggest that doubling debt slows per capita growth by about half to a full percentage point. The differential in per capita growth between countries with external indebtedness (in net present value) below 100 percent of exports and above 300 percent of exports (the latter group composing mostly HIPC countries) seems to be in excess of 2 percent per annum.

- Note that the thresholds for a zero average and marginal impact of debt on growth are similar when estimated using debt in nominal terms or in net present value. This is consistent with the fact that concessional loans are mostly given to countries that already have excessive indebtedness, i.e. above 160-170 percent of exports.

Our result can provide tentative insights in assessing the potential impact of the HIPC debt relief initiative on countries that are scheduled to receive assistance: 
- the debt relief may contribute to increases in per capita growth by about one percent for these countries, and should eliminate the debt-related growth shortfall of HIPC countries relative to low debt developing countries (In fact, by reducing the NPV of debt to 150 percent of exports, debt reduction would eliminate the negative average effect of debt on growth) ${ }^{24}$ However, the theory of the second best may suggest that such a growth dividend might not arise as these economies are often severely affected by other macroeconomic and structural distortions, as well as by high economic and political risks.

- If it were to arise, the increase in growth might initiate a virtuous growth cycle which, in the absence of additional increases in debt levels, would contribute to further reducing debt ratios. However, the results reported above indicate that the HIPC Initiative might reduce the level of indebtedness just to a level where a new increase in debt (which may be likely given the level of development and poverty of these countries) would have a negative impact on growth. In other words, the target debt level of the HIPC initiative remains close to the estimated threshold above which the impact of debt on growth is likely to be negative, and well above the estimated growth-maximizing level of debt. Hence, the HIPC initiative might still leave countries in a danger zone.

It should be noted, however, the economic and political situation of these countries makes them a non-typical sub sample, and further research is therefore necessary to provide a more definitive assessment of the relation between debt and growth for HIPC countries.

In conclusion, we find that the level of investment does not appear to be the main channel through which excessive external indebtedness reduces growth. In fact, all the above results hold in regressions where investment is also controlled for. If we exclude investment from the regressions, the results are similar, although in some cases the debt coefficients become larger, suggesting that only a small part of the impact of debt on growth is through debt contributing to lower investment levels. The result that most of the impact is via the quality rather than the level of investment is consistent with other empirical studies suggesting that total factor productivity accounts for most of the variation in output. ${ }^{25}$ It can also be reconciled with theoretical arguments suggesting that the prospects of future taxation necessary to repay the debt distort the allocation of investment, for example towards short run projects with less positive impact on long-run productivity growth. While our results are suggestive, further theoretical and empirical research will be necessary to provide a better understanding of the channel through which debt affects growth.

\footnotetext{
${ }^{24}$ Note that the historical variability present in the debt data is driven by both decreases and increases in the debt stocks (see, for example, Figure 1), implying that it is reasonable to use the estimated relationships to assess the impact of lowering as well as increasing debt levels.

${ }^{25}$ See Easterly and Levine (2001).
} 
APPENDIX I

\section{LIST OF COUNTRIES}

Algeria, Argentina, Bahrain, Bangladesh, Benin, Bolivia, Botswana, Brazil, Burkina Faso, Burundi, Cambodia, Cameroon, Cape Verde, Central African Rep., Chad, Chile, China P.R.: Mainland, Colombia, Comoros, Congo Dem. Rep. of, Congo Republic of, Costa Rica, Côte D'Ivoire, Cyprus, Djibouti, Dominican Republic, Ecuador, Egypt, El Salvador, Ethiopia, Fiji, Gambia, Ghana, Guatemala, Guinea, Guinea-Bissau, Guyana, Haiti, Honduras, India, Indonesia, Iran, Jamaica, Kenya, Korea, Lao People's Dem. Rep, Lebanon, Lesotho, Libya, Madagascar, Malawi, Malaysia, Mali, Mauritania, Mauritius, Mexico, Morocco, Mozambique, Myanmar, Namibia, Nepal, Nicaragua, Niger, Nigeria, Pakistan, Panama, Papua New Guinea, Paraguay, Peru, Philippines, Rwanda, Senegal, Sierra Leone, Somalia, South Africa, Sri Lanka, Sudan, Suriname, Swaziland, Syrian Arab Republic, Tanzania, Thailand, Togo, Trinidad And Tobago, Tunisia, Turkey, Uganda, Uruguay, Venezuela, Vietnam, Yemen Republic of, Zambia, Zimbabwe. 
Table 1. Summary Statistics ${ }^{1}$

\begin{tabular}{lrrrr}
\hline Variables & Mean & Std. Dev. Minimum & Maximum \\
& & & & \\
& & & & \\
GDP growth & 1.00 & 4.04 & -24.36 & 23.35 \\
Lagged income & 3342.21 & 2930.50 & 414.14 & 25282.07 \\
Terms of trade growth & -0.04 & 9.72 & -37.02 & 40.13 \\
Population growth & 6.96 & 0.96 & 3.27 & 11.71 \\
Debt service to exports & 20.94 & 16.86 & 0.40 & 195.85 \\
Schooling & 35.74 & 22.91 & 2 & 102 \\
Investment & 20.59 & 8.45 & 3.27 & 87.37 \\
Fiscal balance & -4.68 & 4.96 & -31.58 & 15.60 \\
Openness & 28.27 & 19.57 & 1.51 & 115.30 \\
Debt to exports & 288.75 & 383.27 & 3.77 & 4222.92 \\
NPV of debt to exports & 233.62 & 228.06 & 1.60 & 1926.22 \\
Debt to GDP & 68.32 & 82.99 & 1.30 & 914.60 \\
NPV of Debt to GDP & 47.65 & 39.14 & 0.37 & 380.02 \\
& & & & \\
\hline
\end{tabular}

${ }^{1}$ Two observations for Yemen, an extreme outlier with respect to the debt-exports variable, with ratios reaching 20000 percent, were dropped for the computation of sample means. 
Table 2. Correlation Matrix

\begin{tabular}{|c|c|c|c|c|c|c|c|c|c|c|c|c|c|}
\hline Per capita growth & $\begin{array}{l}\text { Per capita } \\
\text { growth }\end{array}$ & ${ }_{1}^{\log \text { (Income })_{1}}$ & $\begin{array}{l}\text { Terms of } \\
\text { trade growth }\end{array}$ & $\begin{array}{l}\text { Log } \\
\text { (Population } \\
\text { h growth) }\end{array}$ & $\begin{array}{l}\text { Debt } \\
\text { service/exports }\end{array}$ & $\begin{array}{l}\text { Log } \\
\text { (Schooling) }\end{array}$ & $\begin{array}{l}\text { Log } \\
\text { (Investment) }\end{array}$ & $\begin{array}{l}\text { Fiscal } \\
\text { Balance }\end{array}$ & Openness & $\begin{array}{l}\text { Log } \\
\text { (Debt/Exports) }\end{array}$ & $\begin{array}{l}\log \text { (NPV of } \\
\text { debt/Exports) }\end{array}$ & $\begin{array}{l}\text { Log } \\
\text { (Debt/GDP) }\end{array}$ & $\begin{array}{l}\log (\text { NPV of } \\
\mathrm{debt/GDP})\end{array}$ \\
\hline $\log (\text { Income })_{1}$ & 0.0195 & 1 & & & & & & & & & & & \\
\hline $\begin{array}{l}\text { Terms of trade } \\
\text { growth }\end{array}$ & $0.1512^{*}$ & 0.0569 & 1 & & & & & & & & & & \\
\hline $\begin{array}{l}\text { Log (Population } \\
\text { growth) }\end{array}$ & $-0.1964 *$ & $-0.253 I^{*}$ & -0.0257 & 1 & & & & & & & & & \\
\hline Debt service/exports & $-0.0992^{*}$ & $0.0845^{*}$ & $-0.0692^{*}$ & -0.0167 & I & & & & & & & & \\
\hline Log (Schooling) & $0.1523 *$ & $0.7017^{*}$ & 0.0292 & $-0.3361 *$ & $0.0925^{*}$ & 1 & & & & & & & \\
\hline $\log$ (Investment) & $0.3269^{*}$ & $0.3149^{*}$ & -0.0034 & $-0.0825 *$ & $-0.0786^{*}$ & $0.3532 *$ & 1 & & & & & & \\
\hline Fiscal Balance & $0.2406^{*}$ & $0.2306^{*}$ & $0.1238^{*}$ & $-0.0845^{*}$ & -0.0157 & $0.0816^{*}$ & $0.0792 *$ & 1 & & & & & \\
\hline Openness & $0.1166^{*}$ & $0.3821^{*}$ & $0.0695^{*}$ & -0.0602 & $-0.2380^{*}$ & $0.3269^{*}$ & $0.3519^{*}$ & $0.0698^{*}$ & 1 & & & & \\
\hline Log (Debt/Exports) & $-0.1880^{*}$ & $-0.4125^{*}$ & $-0.1231^{*}$ & $0.0711^{*}$ & $0.4545^{*}$ & $-0.2035^{*}$ & $-0.2808^{*}$ & $-0.2429 *$ & $-0.4694 *$ & 1 & & & \\
\hline $\begin{array}{l}\text { Log (NPV of } \\
\text { debt'Exports) }\end{array}$ & $-0.1672^{*}$ & $-0.3250^{*}$ & $-0.1223^{*}$ & 0.0038 & $0.4256^{*}$ & $-0.1322^{*}$ & $-0.1480^{*}$ & $-0.2337^{*}$ & $-0.4391^{*}$ & $0.8601^{*}$ & 1 & & \\
\hline Log (Debt/GDP) & $-0.1812^{*}$ & $-0.1969^{*}$ & $-0.1045^{*}$ & $0.0708 *$ & $0.2910^{*}$ & -0.0134 & -0.0408 & $-0.2851^{*}$ & $0.0691 *$ & $0.7213^{*}$ & $0.6464 *$ & 1 & \\
\hline $\begin{array}{l}\text { Log (NPV of } \\
\text { debt/GDP) }\end{array}$ & $-0.1134 *$ & -0.0356 & $-0.0817^{*}$ & -0.0023 & $0.3201^{*}$ & $0.0985^{*}$ & $0.1287^{*}$ & $-0.2001^{*}$ & $0.2427^{*}$ & $0.5386^{*}$ & $0.6527^{*}$ & $0.9003^{*}$ & 1 \\
\hline
\end{tabular}


Table 3. Debt/Exports: Linear and Quadratic Effects on Growth

\begin{tabular}{|c|c|c|c|c|c|c|c|c|}
\hline & & $\overline{\mathrm{LS}}$ & & $\mathrm{V}$ & & $\mathrm{E}$ & & $\mathrm{MM}$ \\
\hline & Linear & Quadratic & Linear & Quadratic & Linear & Quadratic & Linear & Quadratic \\
\hline $\log (\text { Income })_{.1}$ & $-1.94 * * *$ & $-1.94^{* * *}$ & $-1.44 * * *$ & $-1.55^{* * *}$ & $-8.70^{* * *}$ & $-8.66^{* * *}$ & $-3.49^{* * *}$ & $-3.42 * * *$ \\
\hline & $(6.62)$ & $(6.63)$ & $(4.27)$ & $(4.58)$ & $(7.77)$ & (7.64) & $(4.61)$ & $(5.27)$ \\
\hline Terms of trade growth & $0.04 *$ & $0.04 *$ & $0.04 *$ & $0.04 *$ & $0.04 * *$ & $0.04 * *$ & 0.02 & 0.02 \\
\hline & $(1.87)$ & $(1.86)$ & $(1.79)$ & $(1.72)$ & $(2.39)$ & $(2.39)$ & $(1.11)$ & -1.08 \\
\hline Log (population growth) & $-4.71^{* * *}$ & $-4.70 * * *$ & $-4.64^{* * *}$ & $-4.46^{* * *}$ & -4.36 & -4.55 & $-3.86^{* * *}$ & $-3.85^{* * * *}$ \\
\hline & $(4.11)$ & $(4.07)$ & (3.51) & $(3.45)$ & $(1.38)$ & $(1.44)$ & $(2.66)$ & $(2.77)$ \\
\hline Debt service/exports & -0.00 & -0.00 & -0.01 & -0.01 & -0.00 & -0.00 & 0.00 & -0.01 \\
\hline & $(0.15)$ & $(0.31)$ & $(0.80)$ & $(0.82)$ & $(0.09)$ & $(0.14)$ & $(0.16)$ & -0.42 \\
\hline Log (schooling) & $1.17^{* * *}$ & $1.17^{* * *}$ & $1.27^{* * *}$ & $1.24^{* * *}$ & -0.25 & -0.28 & $2.73^{* * *}$ & $2.77 * * *$ \\
\hline & $(4.61)$ & $(4.59)$ & $(3.90)$ & $(3.75)$ & $(0.36)$ & $(0.41)$ & $(3.12)$ & $(3.84)$ \\
\hline Log (investment) & $3.28^{* * *}$ & $3.30^{* * *}$ & $1.97^{* * *}$ & $1.99 * * *$ & $3.74^{* * *}$ & $3.73^{* * *}$ & $1.66^{*}$ & $1.54^{*}$ \\
\hline & $(6.23)$ & $(6.25)$ & $(2.81)$ & $(2.80)$ & $(6.09)$ & $(6.09)$ & $(1.79)$ & $(1.71)$ \\
\hline Fiscal balance & $0.18^{* * *}$ & $0.18^{* * *}$ & 0.08 & 0.06 & $0.20 * * *$ & $0.20^{* * *}$ & $0.33 * * *$ & $0.33^{* * *}$ \\
\hline & $(4.58)$ & $(4.61)$ & $(1.52)$ & $(1.16)$ & $(5.21)$ & $(5.22)$ & $(6.03)$ & $(6.06)$ \\
\hline Openness & -0.00 & 0.00 & -0.00 & -0.00 & 0.03 & 0.03 & 0.02 & 0.02 \\
\hline & $(0.08)$ & $(0.03)$ & $(0.06)$ & $(0.02)$ & $(1.48)$ & $(1.50)$ & $(0.8)$ & $(0.88)$ \\
\hline $\log$ (debt/exports) & -0.37 & 0.29 & -0.16 & $2.87^{*}$ & $-0.97^{* * *}$ & -0.46 & $-0.59 *$ & -0.20 \\
\hline & $(1.47)$ & $(0.33)$ & $(0.52)$ & $(1.79)$ & $(2.74)$ & $(0.38)$ & $(2.43)$ & $(0.18)$ \\
\hline$[\log (\text { debt/exports })]^{2}$ & -- & -0.06 & -- & $-0.30^{* *}$ & - & -0.04 & - & -0.02 \\
\hline & & $(0.84)$ & & $(1.97)$ & & $(0.45)$ & & -0.29 \\
\hline Constant & $16.44^{* * *}$ & $14.65^{* * *}$ & $14.55^{* * *}$ & 7.75 & $79.03 * * *$ & $77.76^{* * *}$ & $28.01 * * *$ & $26.40^{* * * *}$ \\
\hline & $(4.66)$ & $(3.44)$ & $(3.48)$ & (1.54) & $(7.16)$ & $(6.60)$ & $(6.26)$ & $(4.58)$ \\
\hline Number of observations & 630 & 630 & 580 & 580 & 630 & 630 & 614 & 614 \\
\hline R-squared 1/ & 0.29 & 0.29 & 0.25 & 0.24 & 0.52 & 0.52 & 0.23 & 0.23 \\
\hline
\end{tabular}

Note: Absolute value of robust $t$ statistics in parentheses; ${ }^{*}$ significant at $10 \% ; * *$ significant at $5 \% ;{ }^{* * *}$ significant at $1 \%$. All regressions include time dummies.

$1 / 1$ - RSS/TSS reported for system GMM. 
Table 4. Debt/GDP: Linear and Quadratic Effects on Growth

\begin{tabular}{|c|c|c|c|c|c|c|c|c|}
\hline & \multicolumn{2}{|c|}{ OLS } & \multicolumn{2}{|c|}{ IV } & \multicolumn{2}{|c|}{$\mathrm{FE}$} & \multicolumn{2}{|c|}{ SYSGMM } \\
\hline & Linear & Quadratic & Linear & Quadratic & Linear & Quadratic & Linear & Quadratic \\
\hline $\log$ (Income) $)_{-1}$ & $\begin{array}{l}-1.94 * * * \\
(6.75)\end{array}$ & $\begin{array}{l}-2.03 * * * \\
(7.09)\end{array}$ & $\begin{array}{l}-1.50^{* * *} \\
(4.53)\end{array}$ & $\begin{array}{l}-1.52^{* * * *} \\
(4.55)\end{array}$ & $\begin{array}{l}-8.53 * * * \\
(7.66)\end{array}$ & $\begin{array}{l}-9.32^{* * * *} \\
(8.94)\end{array}$ & $\begin{array}{l}-3.45^{* * *} \\
(5.56)\end{array}$ & $\begin{array}{l}-3.54^{* * *} \\
(6.22)\end{array}$ \\
\hline Terms of trade growth & $\begin{array}{c}0.04^{*} \\
(1.88)\end{array}$ & $\begin{array}{c}0.03^{*} \\
(1.80)\end{array}$ & $\begin{array}{r}0.04^{*} \\
(1.82)\end{array}$ & $\begin{array}{c}0.04^{*} \\
(1.76)\end{array}$ & $\begin{array}{l}0.04 * * \\
(2.46)\end{array}$ & $\begin{array}{c}0.04^{* *} \\
(2.34)\end{array}$ & $\begin{array}{c}0.02 \\
(1.07)\end{array}$ & $\begin{array}{c}0.02 \\
(0.98)\end{array}$ \\
\hline Log (population growth) & $\begin{array}{l}-4.56^{* * * *} \\
(3.97)\end{array}$ & $\begin{array}{l}-4.66^{* * * *} \\
(3.95)\end{array}$ & $\begin{array}{l}-4.58^{* * * *} \\
(3.44)\end{array}$ & $\begin{array}{l}-4.57^{* * *} \\
(3.46)\end{array}$ & $\begin{array}{l}-4.48 \\
(1.45)\end{array}$ & $\begin{array}{l}-5.20^{*} \\
(1.73)\end{array}$ & $\begin{array}{l}-3.54 * * \\
(2.49)\end{array}$ & $\begin{array}{l}-3.61^{* * * *} \\
(2.67)\end{array}$ \\
\hline Debt service/exports & $\begin{array}{l}-0.00 \\
(0.02)\end{array}$ & $\begin{array}{l}-0.00 \\
(0.02)\end{array}$ & $\begin{array}{l}-0.01 \\
(0.57)\end{array}$ & $\begin{array}{l}-0.01 \\
(0.64)\end{array}$ & $\begin{array}{l}-0.00 \\
(0.38)\end{array}$ & $\begin{array}{l}-0.00 \\
(0.27)\end{array}$ & $\begin{array}{c}0.00 \\
(0.14)\end{array}$ & $\begin{array}{l}-0.01 \\
(0.37)\end{array}$ \\
\hline Log (schooling) & $\begin{array}{l}1.15^{* * *} \\
(4.50)\end{array}$ & $\begin{array}{l}1.17^{* * * *} \\
(4.60)\end{array}$ & $\begin{array}{l}1.28^{* * *} \\
(3.95)\end{array}$ & $\begin{array}{l}1.27^{* * *} \\
(3.85)\end{array}$ & $\begin{array}{l}-0.35 \\
(0.51)\end{array}$ & $\begin{array}{l}-0.67 \\
(1.05)\end{array}$ & $\begin{array}{l}2.69^{* * * *} \\
(3.76)\end{array}$ & $\begin{array}{l}2.90^{* * *} \\
(4.88)\end{array}$ \\
\hline $\log$ (investment) & $\begin{array}{l}3.35^{* * *} \\
(6.31)\end{array}$ & $\begin{array}{l}3.37^{* * *} \\
(6.33)\end{array}$ & $\begin{array}{l}2.04^{* * * *} \\
(2.90)\end{array}$ & $\begin{array}{l}2.02^{* * * *} \\
(2.87)\end{array}$ & $\begin{array}{l}3.97^{* * *} \\
(6.56)\end{array}$ & $\begin{array}{l}3.92 * * * \\
(6.30)\end{array}$ & $\begin{array}{r}1.63^{*} \\
(1.73)\end{array}$ & $\begin{array}{r}1.58^{*} \\
(1.74)\end{array}$ \\
\hline Fiscal balance & $\begin{array}{l}0.16^{* * *} \\
(4.17)\end{array}$ & $\begin{array}{l}0.15^{* * *} \\
(3.77)\end{array}$ & $\begin{array}{c}0.06 \\
(1.14)\end{array}$ & $\begin{array}{c}0.03 \\
(0.56)\end{array}$ & $\begin{array}{l}0.19^{* * * *} \\
(4.96)\end{array}$ & $\begin{array}{l}0.18^{* * *} \\
(4.76)\end{array}$ & $\begin{array}{l}0.32 * * * * \\
(5.43)\end{array}$ & $\begin{array}{l}0.33^{* * *} \\
(5.84)\end{array}$ \\
\hline Openness & $\begin{array}{c}0.01 \\
(1.15)\end{array}$ & $\begin{array}{c}0.01 \\
(1.40)\end{array}$ & $\begin{array}{c}0.01 \\
(0.47)\end{array}$ & $\begin{array}{c}0.01 \\
(0.57)\end{array}$ & $\begin{array}{l}0.05^{* * *} \\
(2.81)\end{array}$ & $\begin{array}{l}0.05^{* * * *} \\
(2.70)\end{array}$ & $\begin{array}{c}0.04 \\
(1.49)\end{array}$ & $\begin{array}{c}0.03 \\
(1.22)\end{array}$ \\
\hline $\log ($ debt/GDP $)$ & $\begin{array}{l}-0.55^{* *} \\
(2.47)\end{array}$ & $\begin{array}{c}1.25 \\
(1.46)\end{array}$ & $\begin{array}{l}-0.41 \\
(1.51)\end{array}$ & $\begin{array}{c}1.65 \\
(1.33)\end{array}$ & $\begin{array}{l}-1.22 * * * \\
(2.74)\end{array}$ & $\begin{array}{l}2.18^{* *} \\
(2.04)\end{array}$ & $\begin{array}{l}-0.79 \\
(1.52)\end{array}$ & $\begin{array}{c}0.91 \\
(0.22)\end{array}$ \\
\hline$[\log (\operatorname{debt} / \mathrm{GDP})]^{2}$ & -- & $\begin{array}{l}-0.25^{* *} \\
(2.23)\end{array}$ & -- & $\begin{array}{l}-0.28^{*} \\
(1.83)\end{array}$ & - & $\begin{array}{l}-0.48^{* * * *} \\
(3.47)\end{array}$ & -- & $\begin{array}{l}-1.63 \\
(0.38)\end{array}$ \\
\hline Constant & $\begin{array}{l}15.66^{* * *} \\
(4.90)\end{array}$ & $\begin{array}{l}13.31^{* * *} \\
(4.08)\end{array}$ & $\begin{array}{l}14.88^{* * *} \\
(3.85)\end{array}$ & $\begin{array}{l}11.51^{* * *} \\
(2.90)\end{array}$ & $\begin{array}{l}75.75^{* * *} \\
(7.10)\end{array}$ & $\begin{array}{l}78.79^{* * *} \\
(7.94)\end{array}$ & $\begin{array}{l}26.40^{* * *} \\
(5.92)\end{array}$ & $\begin{array}{l}23.98^{* * * *} \\
(3.72)\end{array}$ \\
\hline Number of obscrvations & 630 & 630 & 581 & 581 & 630 & 630 & 614 & 614 \\
\hline R-squared 1/ & 0.30 & 0.30 & 0.26 & 0.26 & 0.52 & 0.54 & 0.23 & 0.22 \\
\hline
\end{tabular}

Note: Absolute value of robust $t$ statistics in parentheses; * significant at $10 \% ;{ }^{* *}$ significant at $5 \% ; * *$ significant at $1 \%$. All regressions include time dummies.

1/ 1 - RSS/TSS reported for system GMM. 
Table 5. Net Present Value of Debt/Exports: Linear and Quadratic Effects on Growth

\begin{tabular}{|c|c|c|c|c|c|c|c|c|}
\hline & \multicolumn{2}{|c|}{ OLS } & \multicolumn{2}{|c|}{ IV } & \multicolumn{2}{|c|}{$\mathrm{FE}$} & \multicolumn{2}{|c|}{ SYSGMM } \\
\hline & Linear & Quadratic & Linear & Quadratic & Linear & Quadratic & Linear & Quadratic \\
\hline \multirow[t]{2}{*}{$\log (\text { Income })_{-1}$} & $-1.76 * * *$ & $-1.76 * * *$ & $-1.23 * * *$ & $-1.27 * * *$ & $-8.75^{* * * * ⿰ ㇇ ⿰ 亅 ⿱ 丿 丶 丶 ~}$ & $-8.72 * * *$ & $-3.77 * * *$ & $-3.62 * * *$ \\
\hline & $(5.69)$ & $(5.70)$ & $(3.42)$ & (3.54) & $(8.07)$ & $(7.98)$ & $(6.02)$ & $(5.81)$ \\
\hline \multirow[t]{2}{*}{ Terms of trade growth } & $0.04 *$ & $0.04^{*}$ & $0.04 *$ & $0.04 *$ & $0.03^{* *}$ & $0.03^{* *}$ & 0.02 & 0.02 \\
\hline & $(1.87)$ & $(1.87)$ & $(1.73)$ & $(1.77)$ & $(2.22)$ & $(2.22)$ & $(1.02)$ & $(1.02)$ \\
\hline \multirow[t]{2}{*}{ Log (population growth) } & $-4.01 * * *$ & $-3.92 * * *$ & $-4.12 * * *$ & $-3.76 * * *$ & -4.33 & -4.50 & $-2.98^{*}$ & $-3.09 *$ \\
\hline & $(3.19)$ & $(3.15)$ & $(3.06)$ & $(2.84)$ & $(1.31)$ & $(1.37)$ & $(2.01)$ & (2.13) \\
\hline \multirow[t]{2}{*}{ Debt service/exports } & -0.00 & -0.00 & -0.02 & -0.02 & -0.01 & -0.01 & -0.01 & -0.01 \\
\hline & $(0.4 I)$ & $(0.48)$ & $(1.43)$ & $(1.52)$ & $(0.69)$ & $(0.70)$ & $(0.5)$ & $(0.74)$ \\
\hline \multirow[t]{2}{*}{ Log (schooling) } & $1.12^{* * *}$ & $1.12 * * *$ & $1.26^{* * * *}$ & $1.25 * * *$ & -0.07 & -0.08 & $3.31^{* * *}$ & $3.14^{* * *}$ \\
\hline & $(4.34)$ & $(4.36)$ & $(3.79)$ & $(3.75)$ & $(0.09)$ & $(0.11)$ & $(4.33)$ & $(4.13)$ \\
\hline \multirow[t]{2}{*}{ Log (investment) } & $3.36 * * *$ & $3.38 * * *$ & $1.96 * * *$ & $2.08 * * *$ & $3.61 * * *$ & $3.63^{* * *}$ & $1.62^{*}$ & $1.81 *$ \\
\hline & $(6.23)$ & $(6.21)$ & $(2.70)$ & $(2.79)$ & $(5.94)$ & $(5.95)$ & $(1.65)$ & $(1.88)$ \\
\hline \multirow[t]{2}{*}{ Fiscal balance } & $0.17^{* * *}$ & $0.17 * * *$ & $0.09^{*}$ & 0.07 & $0.18 * * *$ & $0.18 * * *$ & $0.32 * * *$ & $0.33^{* * *}$ \\
\hline & $(4.43)$ & $(4.43)$ & $(1.75)$ & $(1.35)$ & $(4.84)$ & $(4.85)$ & $(6.33)$ & $(6.35)$ \\
\hline \multirow[t]{2}{*}{ Openness } & -0.00 & -0.00 & 0.00 & -0.00 & $0.06^{* * *}$ & $0.06^{* * *}$ & 0.03 & 0.03 \\
\hline & $(0.13)$ & $(0.16)$ & $(0.24)$ & $(0.04)$ & $(3.03)$ & $(3.02)$ & $(1.36)$ & $(1.41)$ \\
\hline \multirow[t]{2}{*}{$\log$ (debt/exports) } & -0.38 & 0.29 & 0.12 & 4.02 & $-0.82 * *$ & -0.19 & $-0.45 *$ & 0.41 \\
\hline & $(1.52)$ & $(0.37)$ & $(0.30)$ & $(1.35)$ & $(2.32)$ & $(0.19)$ & $(1.66)$ & $(0.45)$ \\
\hline \multirow[t]{2}{*}{$\log (\text { debt/exports) }]^{2}$} & - & -0.07 & -- & -0.39 & -. & -0.06 & -- & -0.07 \\
\hline & & $(0.94)$ & & $(1.39)$ & & $(0.69)$ & & $(1.03)$ \\
\hline \multirow[t]{2}{*}{ Constant } & $13.67^{* * *}$ & $11.81^{* * *}$ & $10.83 * *$ & 0.81 & $78.21^{* * *}$ & $76.75^{* * *}$ & $25.77 * * *$ & $22.42^{* * *}$ \\
\hline & $(3.78)$ & $(2.93)$ & $(2.54)$ & $(0.10)$ & $(6.85)$ & $(6.34)$ & $(4.98)$ & $(3.73)$ \\
\hline Number of observations & 606 & 606 & 562 & 562 & 606 & 606 & 592 & 592 \\
\hline R-squared 1/ & 0.27 & 0.28 & 0.25 & 0.23 & 0.51 & 0.51 & 0.17 & 0.19 \\
\hline
\end{tabular}

Note: Absolute value of robust $t$ statistics in parentheses; ${ }^{*}$ significant at $10 \% ; * *$ significant at $5 \% ; * * *$ significant at $1 \%$. All regressions include time dummies

1/ 1 - RSS/TSS reported for system GMM. 
Table 6. Net Present Value of Debt/GDP; Linear and Quadratic Effects on Growth

\begin{tabular}{|c|c|c|c|c|c|c|c|c|}
\hline & \multicolumn{2}{|c|}{ OLS } & \multicolumn{2}{|c|}{ IV } & \multicolumn{2}{|c|}{$\mathrm{FE}$} & \multicolumn{2}{|c|}{ SYSGMM } \\
\hline & Linear & Quadratic & Linear & Quadratic & Linear & Quadratic & Linear & Quadratic \\
\hline $\log (\text { (ncome })_{-1}$ & $\begin{array}{l}-1.71 * * * \\
(5.59)\end{array}$ & $\begin{array}{l}-1.74 * * * \\
(5.73)\end{array}$ & $\begin{array}{l}-1.30^{* * *} \\
(3.77)\end{array}$ & $\begin{array}{l}-1.26 * * * \\
(3.59)\end{array}$ & $\begin{array}{l}-8.59^{* * *} \\
(8.00)\end{array}$ & $\begin{array}{l}-9.21 * * * \\
(9.03)\end{array}$ & $\begin{array}{l}-3.18 * * * \\
(4.97)\end{array}$ & $\begin{array}{l}-3.41 * * * \\
(5.57)\end{array}$ \\
\hline Terms of trade growth & $\begin{array}{r}0.04^{*} \\
(1.88)\end{array}$ & $\begin{array}{r}0.04 * \\
(1.86)\end{array}$ & $\begin{array}{r}0.04^{*} \\
(1.78)\end{array}$ & $\begin{array}{r}0.04 * \\
(1.77)\end{array}$ & $\begin{array}{l}0.04^{* *} \\
(2.29)\end{array}$ & $\begin{array}{l}0.03^{* *} \\
(2.17)\end{array}$ & $\begin{array}{c}0.02 \\
(1.09)\end{array}$ & $\begin{array}{c}0.02 \\
(1.06)\end{array}$ \\
\hline Log (population growth) & $\begin{array}{l}-3.96^{* * *} \\
(3.14)\end{array}$ & $\begin{array}{l}-3.75^{* * *} \\
(3.03)\end{array}$ & $\begin{array}{l}-4.17^{* * *} \\
(3.08)\end{array}$ & $\begin{array}{l}-3.94^{* * * *} \\
(2.99)\end{array}$ & $\begin{array}{l}-3.96 \\
(1.22)\end{array}$ & $\begin{array}{l}-4.08 \\
(1.28)\end{array}$ & $\begin{array}{l}-3.75^{* * * *} \\
(2.66)\end{array}$ & $\begin{array}{l}-3.67^{*} \\
(2.32)\end{array}$ \\
\hline Debt service/exports & $\begin{array}{l}-0.00 \\
(0.16)\end{array}$ & $\begin{array}{c}0.00 \\
(0.13)\end{array}$ & $\begin{array}{l}-0.01 \\
(0.81)\end{array}$ & $\begin{array}{l}-0.01 \\
(0.78)\end{array}$ & $\begin{array}{l}-0.01 \\
(0.75)\end{array}$ & $\begin{array}{l}-0.01 \\
(0.46)\end{array}$ & $\begin{array}{l}-0.01 \\
(0.69)\end{array}$ & $\begin{array}{c}0.00 \\
(0.25)\end{array}$ \\
\hline Log (schooling) & $\begin{array}{l}1.09 * * * \\
(4.22)\end{array}$ & $\begin{array}{l}1.10^{* * * *} \\
(4.25)\end{array}$ & $\begin{array}{l}1.25 * * * \\
(3.78)\end{array}$ & $\begin{array}{l}1.22^{* * * *} \\
(3.62)\end{array}$ & $\begin{array}{l}-0.11 \\
(0.15)\end{array}$ & $\begin{array}{l}-0.22 \\
(0.31)\end{array}$ & $\begin{array}{l}2.48 * * * \\
(3.03)\end{array}$ & $\begin{array}{l}2.65^{* * *} \\
(3.34)\end{array}$ \\
\hline Log (investment) & $\begin{array}{l}3.43^{* * *} \\
(6.32)\end{array}$ & $\begin{array}{l}3.50^{* * *} \\
(6.39)\end{array}$ & $\begin{array}{l}2.08^{* * * *} \\
(2.87)\end{array}$ & $\begin{array}{l}2.17^{* * * *} \\
(2.95)\end{array}$ & $\begin{array}{l}3.81^{* * *} \\
(6.20)\end{array}$ & $\begin{array}{l}3.91^{* * *} \\
(6.27)\end{array}$ & $\begin{array}{r}2.12^{*} \\
(2.25)\end{array}$ & $\begin{array}{r}1.94^{*} \\
(2.12)\end{array}$ \\
\hline Fiscal balance & $\begin{array}{l}0.17^{* * *} \\
(4.18)\end{array}$ & $\begin{array}{l}0.15^{* * *} \\
(3.59)\end{array}$ & $\begin{array}{l}0.07 \\
(1.31)\end{array}$ & $\begin{array}{l}0.03 \\
(0.54)\end{array}$ & $\begin{array}{l}0.18^{* * * *} \\
(4.93)\end{array}$ & $\begin{array}{l}0.17^{* * * *} \\
(4.68)\end{array}$ & $\begin{array}{l}0.31^{* * *} \\
(5.67)\end{array}$ & $\begin{array}{l}0.29 * * * \\
(5.35)\end{array}$ \\
\hline Openness & $\begin{array}{c}0.01 \\
(1.21)\end{array}$ & $\begin{array}{c}0.02 \\
(1.50)\end{array}$ & $\begin{array}{c}0.01 \\
(0.49)\end{array}$ & $\begin{array}{c}0.01 \\
(0.51)\end{array}$ & $\begin{array}{l}0.08^{* * * *} \\
(3.69)\end{array}$ & $\begin{array}{l}0.09 * * * \\
(3.92)\end{array}$ & $\begin{array}{c}0.04^{* *} \\
(1.96)\end{array}$ & $\begin{array}{l}0.06^{* *} \\
(2.44)\end{array}$ \\
\hline $\log ($ debt/GDP) & $\begin{array}{l}-0.53^{* *} \\
(2.01)\end{array}$ & $\begin{array}{r}1.30^{*} \\
(1.89)\end{array}$ & $\begin{array}{l}-0.34 \\
(1.00)\end{array}$ & $\begin{array}{c}2.19 \\
(1.28)\end{array}$ & $\begin{array}{l}-0.84 * * \\
(2.06)\end{array}$ & $\begin{array}{l}2.07^{* *} \\
(2.41)\end{array}$ & $\begin{array}{l}-0.10 \\
(0.23)\end{array}$ & $\begin{array}{l}1.27^{*} \\
(1.81)\end{array}$ \\
\hline$[\log (\operatorname{debt} / \mathrm{GDP})]^{2}$ & -- & $\begin{array}{l}-0.30^{* * *} \\
(2.70)\end{array}$ & -- & $\begin{array}{l}-0.39 \\
(1.62)\end{array}$ & -- & $\begin{array}{l}-0.51^{* * *} \\
(3.68)\end{array}$ & - & $\begin{array}{l}-0.24^{*} \\
(1.74)\end{array}$ \\
\hline Constant & $\begin{array}{l}12.49^{* * *} \\
(3.60)\end{array}$ & $\begin{array}{l}9.19^{* *} \\
(2.58)\end{array}$ & $\begin{array}{l}12.42 * * * \\
(3.14)\end{array}$ & $\begin{array}{l}7.36 \\
(1.51)\end{array}$ & $\begin{array}{l}73.68 * * * \\
(6.95)\end{array}$ & $\begin{array}{l}74.52^{* * *} \\
(7.25)\end{array}$ & $\begin{array}{l}21.74 * * * \\
(4.92)\end{array}$ & $\begin{array}{l}20.88^{* * * *} \\
(4.86)\end{array}$ \\
\hline Number of observations & 606 & 606 & 562 & 562 & 606 & 606 & 592 & 592 \\
\hline R-squared 1/ & 0.28 & 0.29 & 0.25 & 0.25 & 0.51 & 0.52 & 0.24 & 0.22 \\
\hline
\end{tabular}

Note: Absolute value of robust $t$ statistics in parentheses; ${ }^{*}$ significant at $10 \% ;{ }^{* *}$ significant at $5 \% ;{ }^{* * *}$ significant at $1 \%$. All regressions include time dummies.

1/ 1 - RSS/TSS reported for system GMM. 
Table 7. Debt Dummy Thresholds $1 /$

\begin{tabular}{lcccc} 
& Debt/Exports & Debt/GDP & $\begin{array}{c}\text { NPV of Debt/ } \\
\text { Exports }\end{array}$ & $\begin{array}{c}\text { NPV of } \\
\text { Debt/GDP }\end{array}$ \\
\hline OLS and fixed effects: & & & & \\
Quintile 1 & 0 & 0 & 0 & 0 \\
Quintile 2 & 100 & 25 & 94 & 21 \\
Quintile 3 & 165 & 40 & 156 & 33 \\
Quintile 4 & 244 & 59 & 225 & 47 \\
Quintile 5 & 367 & 95 & 306 & 67 \\
Instrumental variables: & & & & \\
Quintile 1 & 0 & 0 & 0 & 0 \\
Quintile 2 & 98 & 28 & 106 & 25 \\
Quintile 3 & 175 & 43 & 168 & 36 \\
Quintilc 4 & 252 & 64 & 233 & 51 \\
Quintile 5 & 376 & 101 & 312 & 70 \\
& & & & \\
\hline
\end{tabular}

1/ The threshold reported is the lower bound of the respective quintiles. 
Table 8. Debt Turning Point (with investment)

\begin{tabular}{|c|c|c|c|c|}
\hline & Debt to Exports & Debt to GDP & $\begin{array}{l}\text { Net Present Value } \\
\text { of Debt to Exports }\end{array}$ & $\begin{array}{l}\text { Net Present Value } \\
\text { of Debt to GDP }\end{array}$ \\
\hline & \multicolumn{4}{|c|}{ Quadratic model 1/ } \\
\hline OLS & 0.03 & 5.80 & 0.05 & 6.55 \\
\hline With time dummies & 11.75 & 12.30 & 9.36 & 8.69 \\
\hline Without outliers & 39.97 & 5.55 & 0.04 & 2.30 \\
\hline With time dummies and without outliers & 87.33 & 13.17 & 17.72 & 5.99 \\
\hline IV & 101.56 & 13.04 & 111.53 & 14.39 \\
\hline With time dummies & 115.46 & 19.04 & 164.84 & 16.75 \\
\hline Without outliers & 33.75 & 0.20 & 47.85 & 4.46 \\
\hline With time dummies and without outliers & 46.52 & 0.58 & 0.20 & 6.10 \\
\hline Fixed effects & 4.36 & 18.01 & 0.67 & 10.70 \\
\hline With time dummies & 0.00 & 9.76 & 0.20 & 7.67 \\
\hline Without outliers & 76.27 & 19.26 & 18.00 & 12.57 \\
\hline With time dummies and without outliers & 45.26 & 10.55 & 19.38 & 9.05 \\
\hline \multirow{2}{*}{$\begin{array}{l}\text { System GMM with time dummies and } \\
\text { without outliers }\end{array}$} & 0.01 & 1.32 & 22.41 & 13.57 \\
\hline & \multicolumn{4}{|c|}{ Spline 2/ } \\
\hline \multicolumn{5}{|l|}{ (With time dummies and without outliers) } \\
\hline OLS & 28.33 & 90.02 & 30 & 148.41 \\
\hline IV & 28.3 & 81.5 & 134.3 & 27 \\
\hline Fixed effects $3 /$ & 94.07 & 44.70 & $665.13 /$ & 49.40 \\
\hline System GMM & 117.21 & 37.49 & 69.30 & 62.93 \\
\hline
\end{tabular}

1/ Let D represent debt variables, (Debt/Exports, Debt/GDP, NPV of Debt/Exports, NPV of Debt/GDP) turning points calculated as $\exp \left[-\beta_{\mathrm{D}} /\left(2 \beta_{\mathrm{D} 2}\right)\right]$.

2/ Turning points calculated as $\exp \left[\log D^{*}\right]$, where $D^{*}$ maximizes the $R^{2}$ in a regression including $\left[D+\left(D-D^{*}\right) H D\right]$, where $\mathrm{HD}=1$ if $\mathrm{D}>\mathrm{D}^{*}, 0$ otherwise.

3/ Two other local maxima with similar R-squareds were found in this case: $33.1 \%$ and $109.9 \%$. 
Table 9. Effects of Doubling Debt on Growth (with investment)

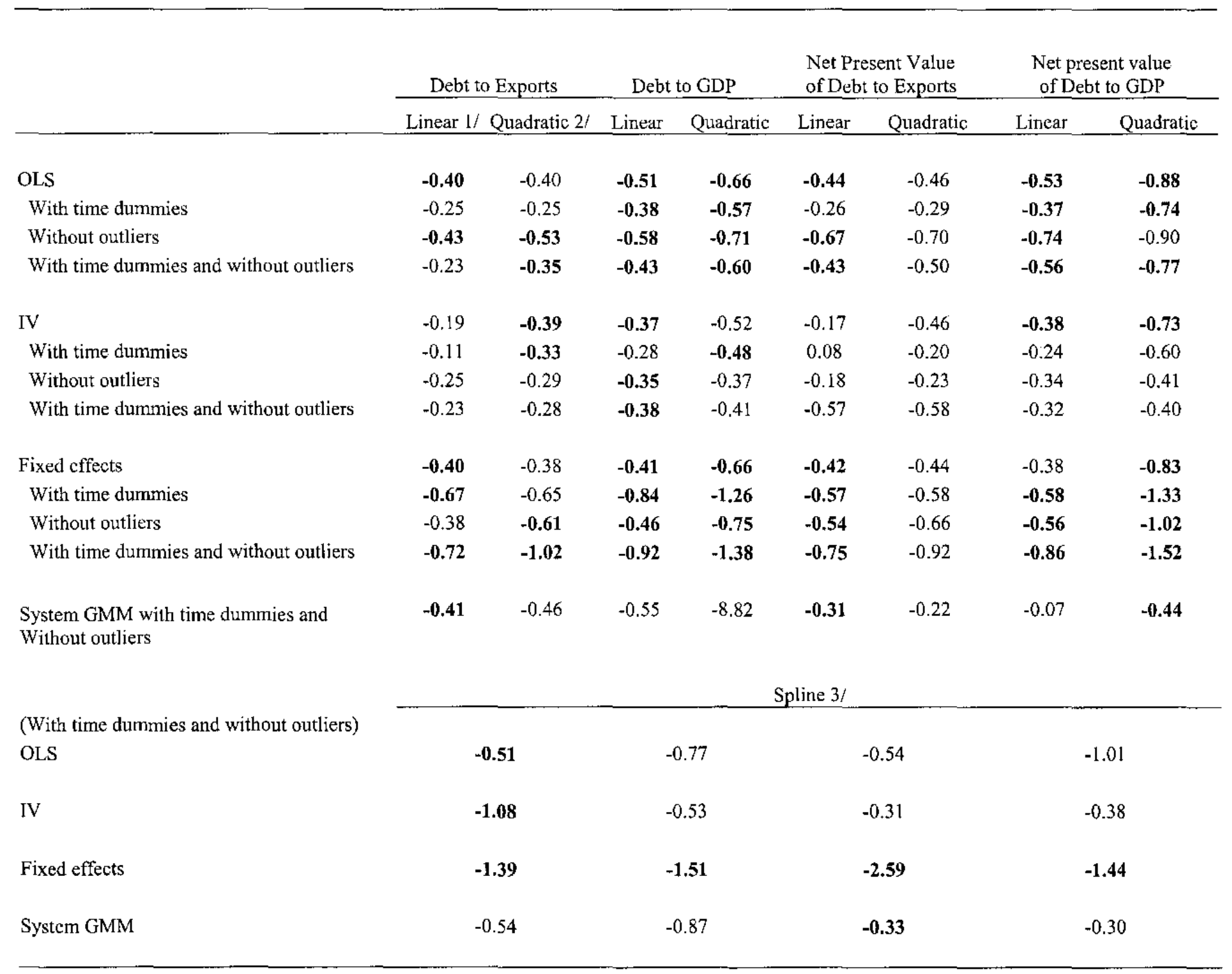

$1 /$ Computed as $\log (2) * \beta_{\mathrm{D}}$, where $\mathrm{D}$ represents debt variables.

$2 /$ Computed at the average, that is, as $\log (2) * \beta_{\mathrm{D}}+\beta_{\mathrm{D} 2} *[\log (2)]^{2}+2 * \log (2)^{*} \beta_{\mathrm{D} 2} *$ avcrage $\log (\mathrm{D})$.

The average log of debt was about (once exponentiated): Debt/Exports: 182\%; Debt/GDP 46\%; NPV of Debt/Exports $170 \%$; NPV of Debt/GDP; $36 \%$.

3/ Computed as $\log (2)^{*} \beta_{D}^{*} \beta_{\text {Extra, Extra }}=\left[D+\left(D-D^{*}\right) H D\right]$, where $H D=1$ if $D>D^{*}, 0$ otherwise. Shows impact on growth of doubling debt at the spline threshold, identified in Table 8. 
Table 10. Effects of Doubling Debt on Growth (without investment)

\begin{tabular}{|c|c|c|c|c|c|c|c|c|}
\hline & \multicolumn{2}{|c|}{ Debt to Exports } & \multicolumn{2}{|c|}{ Debt to GDP } & \multicolumn{2}{|c|}{$\begin{array}{l}\text { Net Present Value } \\
\text { of Debt to Exports }\end{array}$} & \multicolumn{2}{|c|}{$\begin{array}{l}\text { Net Present } \\
\text { Valuc of Debt to } \\
\text { GDP }\end{array}$} \\
\hline & Linear $1 /$ & Quadratic 2/ & Linear & Quadratic & Linear & Quadratic & Linear & Quadratic \\
\hline OLS & -0.51 & -0.51 & -0.55 & -0.69 & -0.38 & -0.40 & -0.43 & -0.74 \\
\hline With time dummies & -0.35 & -0.35 & -0.37 & -0.54 & -0.15 & -0.17 & -0.20 & -0.48 \\
\hline Without outliers & -0.56 & -0.65 & -0.61 & -0.73 & -0.63 & -0.64 & -0.63 & -0.73 \\
\hline With time dummies and without outliers & -0.34 & -0.45 & -0.41 & -0.56 & -0.31 & -0.35 & -0.35 & -0.47 \\
\hline IV & -0.27 & -0.44 & -0.41 & -0.56 & -0.14 & -0.39 & -0.36 & -0.69 \\
\hline With time dummies & -0.17 & -0.37 & -0.29 & -0.48 & 0.18 & -0.05 & -0.15 & -0.46 \\
\hline Without outliers & -0.35 & -0.37 & -0.42 & -0.42 & -0.20 & -0.20 & -0.34 & -0.34 \\
\hline With time dummics and without outliers & -0.30 & -0.32 & -0.41 & -0.42 & -0.43 & -0.44 & -0.22 & -0.22 \\
\hline Fixed effects & -0.51 & -0.48 & -0.46 & -0.90 & -0.43 & -0.44 & -0.20 & -0.87 \\
\hline With time dummies & -0.35 & -0.33 & -0.26 & -0.55 & -0.36 & -0.38 & -0.17 & -0.64 \\
\hline Without outliers & -0.33 & -0.56 & -0.32 & -0.64 & -0.50 & -0.62 & -0.35 & -0.89 \\
\hline With time dummies and without outliers & -0.54 & -0.84 & -0.55 & -1.04 & -0.61 & -0.76 & -0.43 & -1.14 \\
\hline $\begin{array}{l}\text { System GMM with time dummies and } \\
\text { Without ouliers }\end{array}$ & -.048 & -.037 & -0.60 & -7.31 & -0.38 & -0.83 & -0.02 & -0.39 \\
\hline
\end{tabular}

$1 /$ Computed as $\log (2) * \beta_{\mathrm{D}}$, where $\mathrm{D}$ represents debt variables.

$2 /$ Computed at the average, that is, as $\log (2) * \beta_{\mathrm{D}}+\beta_{\mathrm{D} 2} *[\log (2)]^{2}+2 * \log (2)^{*} \beta_{\mathrm{D} 2} *$ average $\log (\mathrm{D})$. 
Table 11. Effects of Doubling Debt on Growth (panel decades, with investment)

\begin{tabular}{|c|c|c|c|c|c|c|c|c|}
\hline & \multicolumn{2}{|c|}{ Debt to Exports } & \multicolumn{2}{|c|}{ Debt to GDP } & \multicolumn{2}{|c|}{$\begin{array}{c}\text { Net Present Value of } \\
\text { Debt to Exports }\end{array}$} & \multicolumn{2}{|c|}{$\begin{array}{c}\text { Net present value of } \\
\text { debt to GDP }\end{array}$} \\
\hline & Linearl/ & Quadratic2/ & Linear & Quadratic & Lincar & Quadratic & Linear & Quadratic \\
\hline OLS & -0.34 & -0.60 & -0.41 & -0.68 & -0.67 & -0.74 & -0.75 & -1.09 \\
\hline With time dummies & -0.22 & -0.43 & -0.30 & -0.57 & -0.47 & -0.53 & -0.60 & -0.94 \\
\hline Without outliers & $-0,49$ & -0.52 & -0.58 & -0.85 & -0.67 & -0.73 & -0.75 & -1.06 \\
\hline With time dummies and without outliers & -0.32 & -0.34 & -0.46 & -0.74 & -0.56 & -0.58 & -0.61 & -0.90 \\
\hline IV & -0.10 & -0.01 & -0.21 & -0.14 & -0.27 & -0.25 & -0.30 & 0.35 \\
\hline With time dummies & -0.16 & -0.02 & -0.32 & -0.29 & -0.56 & -0.58 & -0.58 & 0.39 \\
\hline Without outliers & -0.04 & -0.04 & -0.21 & -0.18 & -0.21 & -0.20 & -0.32 & 0.16 \\
\hline With time dummies and without outliers & -0.16 & .0 .16 & -0.56 & -0.45 & -0.80 & -0.74 & -1.12 & -0.37 \\
\hline Fixed effects & -0.22 & -0.53 & -0.23 & -0.49 & -0.52 & -0.67 & -0.50 & -1.05 \\
\hline With time dummies & -0.25 & -0.72 & -0.29 & -0.85 & -0.62 & -0.83 & -0.63 & -1.63 \\
\hline Without outliers & -0.36 & -0.49 & -0.35 & -0.67 & -0.55 & -0.81 & -0.52 & -1.09 \\
\hline With time dummies and without outliers & -0.53 & -0.67 & -0.61 & -1.09 & -0.60 & -0.92 & -0.59 & -1.52 \\
\hline
\end{tabular}

$1 /$ Computed as $\log (2) * \beta_{D}$, where $\mathrm{D}$ represents debt variables.

$2 /$ Computed at the average, that is, as $\log (2) * \beta_{\mathrm{D}}+\beta_{\mathrm{D} 2} *[\log (2)]^{2}+2 * \log (2) * \beta_{\mathrm{D} 2} *$ average $\log (\mathrm{D})$.

The average log of debt was about (once exponentiated): Debt/Exports: 182\%; Debt/GDP 46\%; NPV of Debt/Exports 170\%; NPV of Debt/GDP: 36\%. 
Table 12. Effects of Halving Debt on Growth (for HIPCs that reached the decision point)

\begin{tabular}{|c|c|c|c|c|c|c|c|c|}
\hline & \multirow{2}{*}{\multicolumn{2}{|c|}{ Debt to exports }} & \multicolumn{2}{|c|}{ Debt to GDP } & \multicolumn{2}{|c|}{$\begin{array}{l}\text { Net present value of } \\
\text { debt to exports }\end{array}$} & \multicolumn{2}{|c|}{$\begin{array}{l}\text { Net present value of } \\
\text { debt to GDP }\end{array}$} \\
\hline & & & (Quad & Iratic) & (Quad & dratic) & (Quac & Aratic) \\
\hline & $\begin{array}{c}\text { With } \\
\text { Investment }\end{array}$ & $\begin{array}{c}\text { Without } \\
\text { Investment }\end{array}$ & $\begin{array}{c}\text { With } \\
\text { Investment }\end{array}$ & $\begin{array}{l}\text { Without } \\
\text { Investment }\end{array}$ & $\begin{array}{c}\text { With } \\
\text { Investment }\end{array}$ & $\begin{array}{l}\text { Without } \\
\text { Investment }\end{array}$ & $\begin{array}{c}\text { With } \\
\text { Investment }\end{array}$ & $\begin{array}{l}\text { Without } \\
\text { Investment }\end{array}$ \\
\hline OLS & 0.42 & 0.51 & 0.83 & 0.85 & 0.45 & 0.39 & 0.93 & 0.78 \\
\hline With time dummies & 0.29 & 0.37 & 0.78 & 0.74 & 0.28 & 0.17 & 0.78 & 0.52 \\
\hline Without outliers & 0.69 & 0.79 & 0.89 & 0.89 & 0.69 & 0.63 & 0.94 & 0.75 \\
\hline With time dummies and without outliers & $\mathbf{0 . 5 3}$ & 0.60 & 0.83 & 0.77 & 0.47 & 0.34 & 0.81 & 0.49 \\
\hline IV & 0.62 & 0.65 & 0.71 & 0.75 & 0.39 & 0.33 & 0.79 & 0.75 \\
\hline With time dummies & 0.56 & 0.57 & 0.71 & 0.72 & 0.14 & -0.01 & 0.66 & 0.51 \\
\hline Without outliers & 0.37 & 0.41 & 0.41 & 0.43 & 0.21 & 0.20 & 0.43 & 0.34 \\
\hline With time dummies and without outliers & 0.37 & 0.37 & 0.47 & 0.44 & 0.57 & 0.43 & 0.42 & 0.23 \\
\hline Fixed effects & 0.43 & 0.38 & 0.97 & 0.89 & 0.43 & 0.37 & 0.89 & 0.71 \\
\hline With time dummies & 0.68 & 0.52 & 1.66 & 1.32 & 0.57 & 0.43 & 1.41 & 0.94 \\
\hline Without outliers & 0.88 & 0.85 & 1.13 & 1.05 & 0.63 & 0.59 & 1.10 & 0.98 \\
\hline With time dummies and without outliers & 1.34 & 1.16 & 1.83 & 1.52 & 0.88 & 0.72 & 1.62 & 1.25 \\
\hline $\begin{array}{l}\text { System GMM with time dummies and } \\
\text { Without outliers }\end{array}$ & 0.44 & -- & 10.19 & -. & 0.21 & -- & 0.48 & -- \\
\hline
\end{tabular}

$1 /$ Computed at the average, that is, as $\log (2) * \beta_{\mathrm{D}}+[\log (2)]^{2 *} \beta_{\mathrm{D} 2}+2 * \log (2) * \beta_{\mathrm{D} 2} * \log$ (average D for $22 \mathrm{HIPCs}$ ).

The averages are 1999 figures for the 22 HIPCs that reached their decision point by 2001: Debt/Exports: 625\%; Debt/GDP:169\%; NPV of Debt/Exports: 300\% NPV of Debt/GDP: $80 \%$

NPV ratios are from IMF (2001), nominal debt ratios from Global Development Finance. 
Figure 1. Growth and debt indicators over time
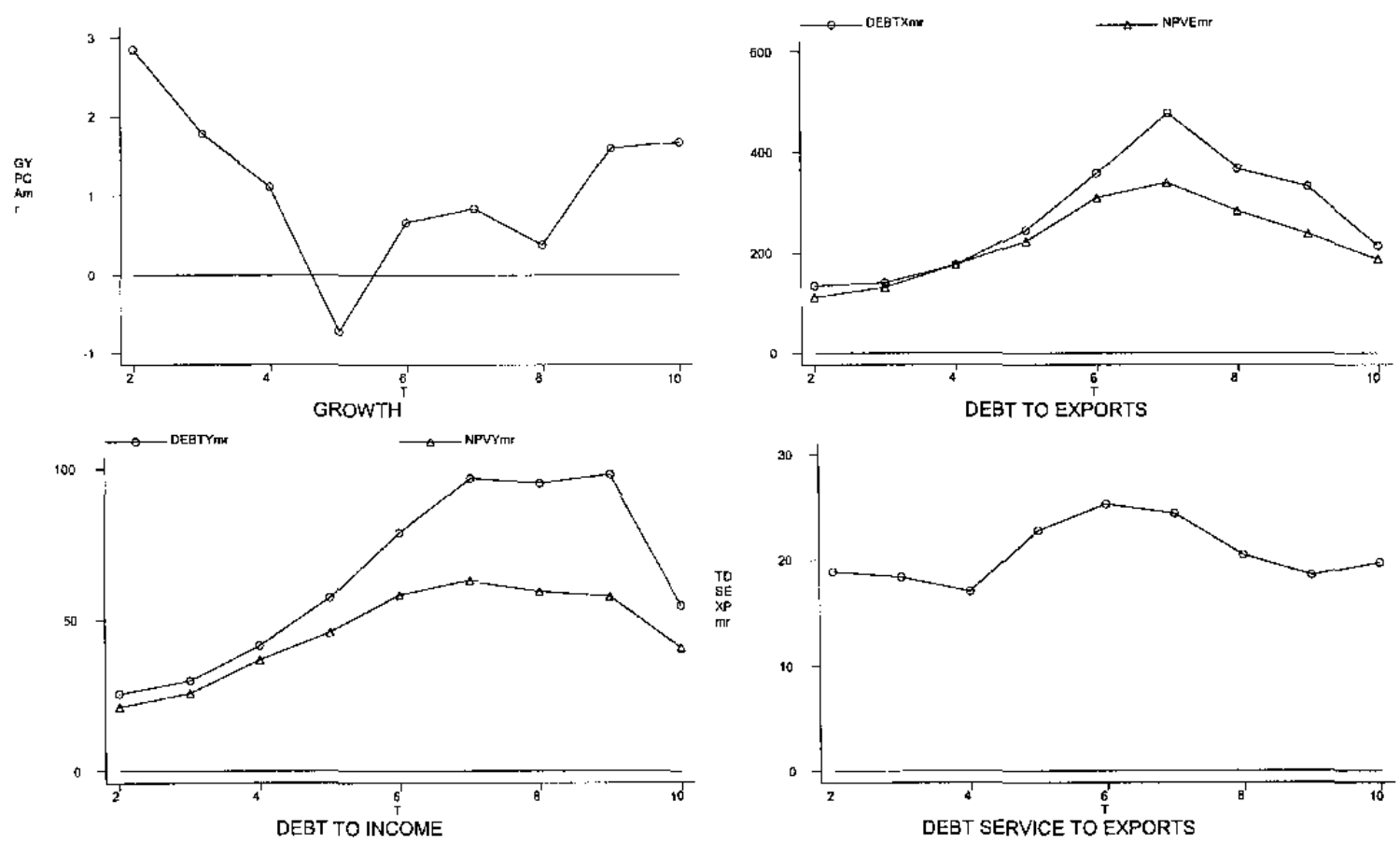

Notes:

1. DEBTXmr is Debt/Exports; NPVEmr is NPV of Debt/Exports; DEBTYmr is Debt/GDP; and NPVYmr is NPV of Debt/GDP.

2. The horizontal axis is measured in 3 -year period averages starting with the period 1972-74 up to $1996-98$.

3. Two observations for Yemen, an extreme outlier with respect to the debt-exports variable, were dropped for the computation of sample means. 
Figure 2. Growth and Debt Indicators Over Time, Without Outliers
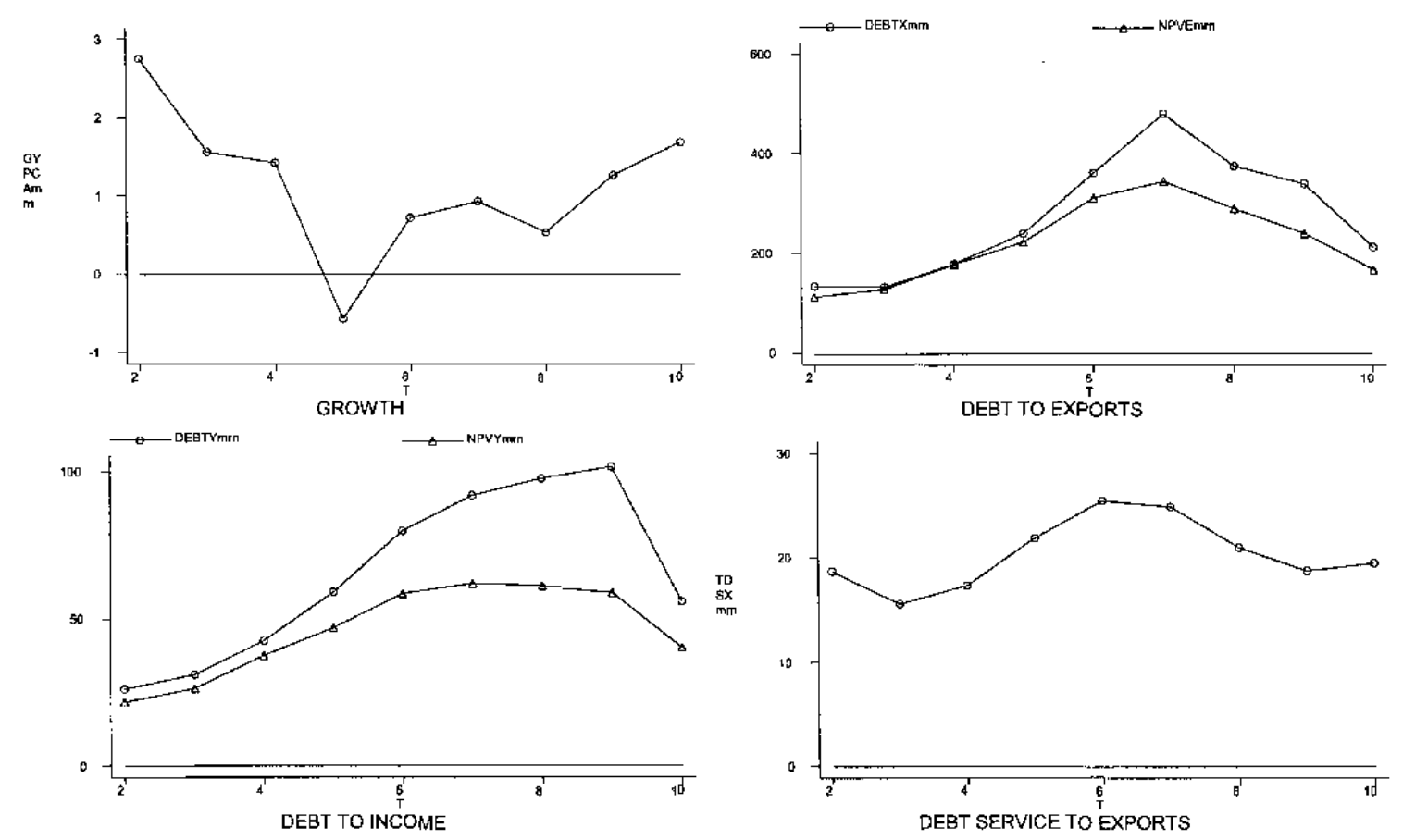

\section{Notes:}

1. DEBTXmr is Debt/Exports; NPVEmr is NPV of Debt/Exports; DEBTYmr is Debt/GDP; and NPVYmr is NPV of Debt/GDP.

2. The horizontal axis is measured in 3-year period averages starting with the period $1972-74$ up to $1996-98$.

3. Two observations for Yemen, an extreme outlier with respect to the debt-exports variable, were dropped for the computation of sample means. 
Figure 3. Debt to Exports, Without Outliers, OLS, IV, FE
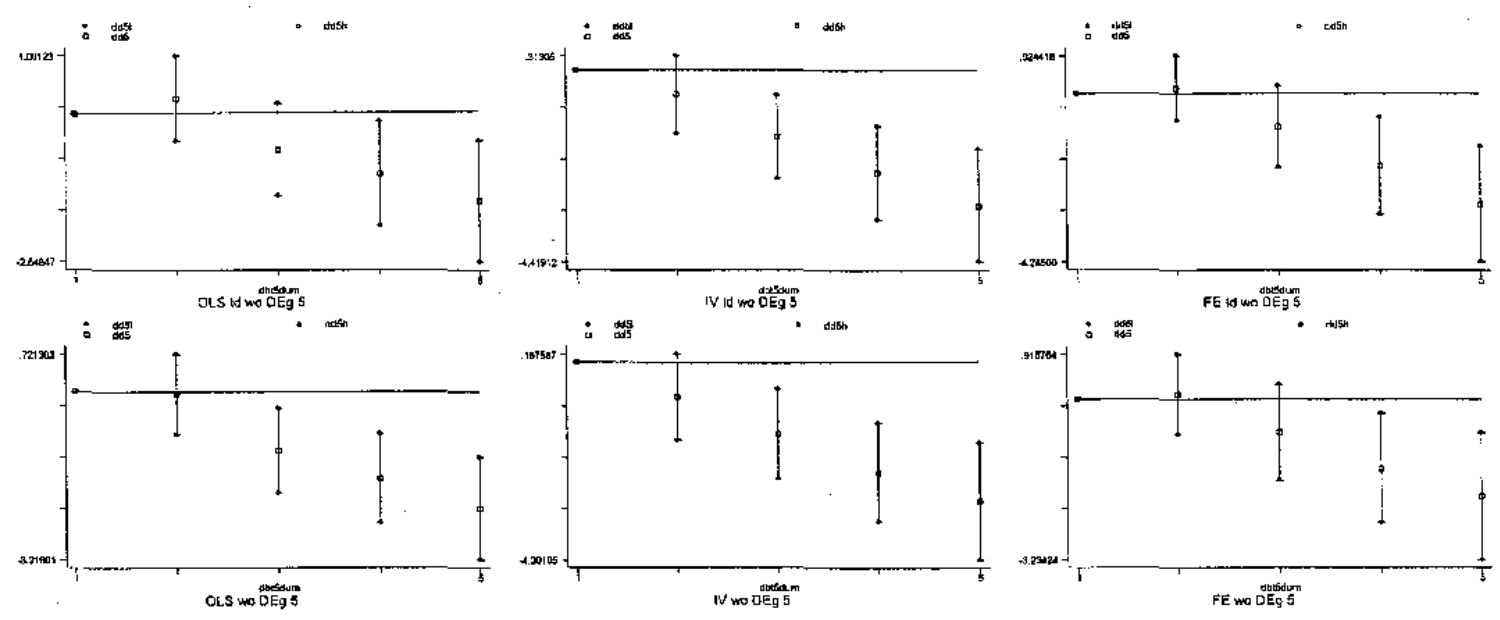

Notes:

1. Each chart plots for the second to fifth debt quintile dummies (horizontal axis) the coefficient estimate of the dummy with its 95 percent confidence interval (vertical axis). The first dummy is excluded from the regression so each coefficient estimate measures the growth differential (ceteris paribus) with respect to the first debt quintile.

2 . The first row represents estimations with time dummies and without outliers. The second row represents estimations without time dummies and without ouliers.

3. The estimations are shown for OLS, IV, and FE methods. 
Figure 4. NPV of Debt to Exports, Without Outliers PLS, IV, FE
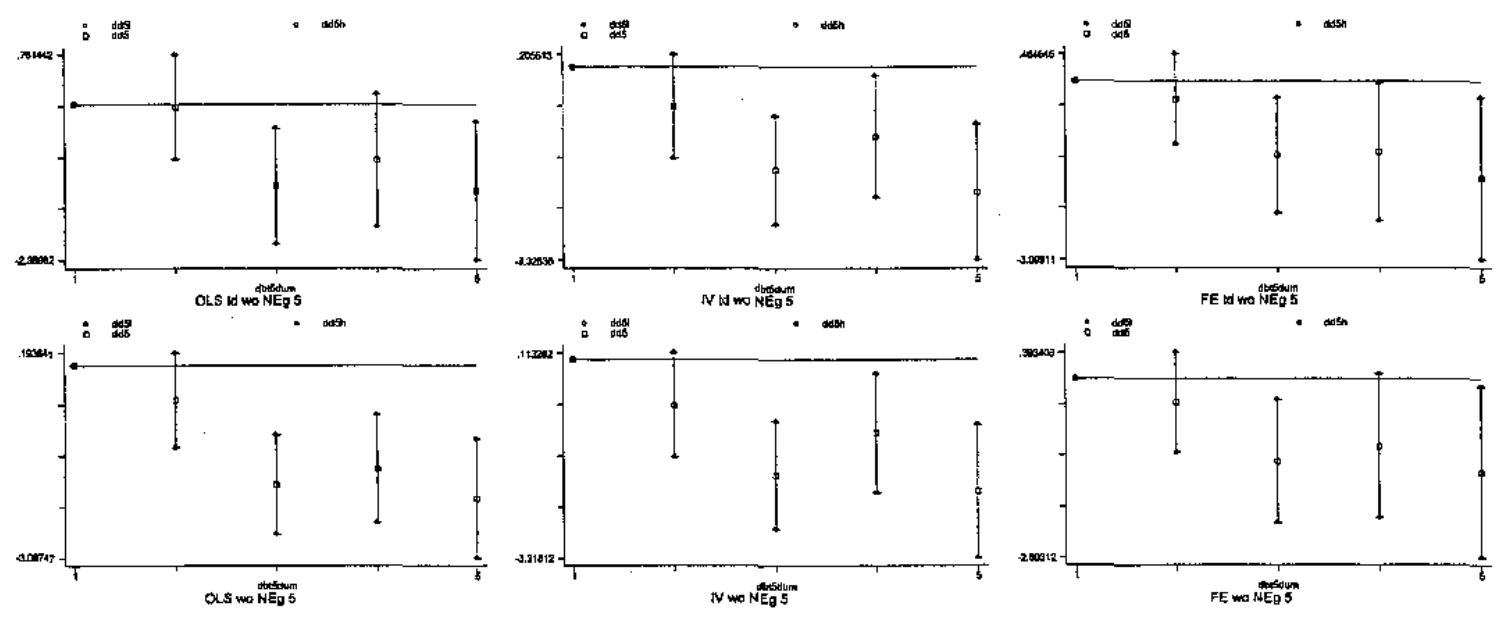

See footnote in Figure 3. 
Figure 5. Debt to GDP Without Outliers, OLS, IV, FE

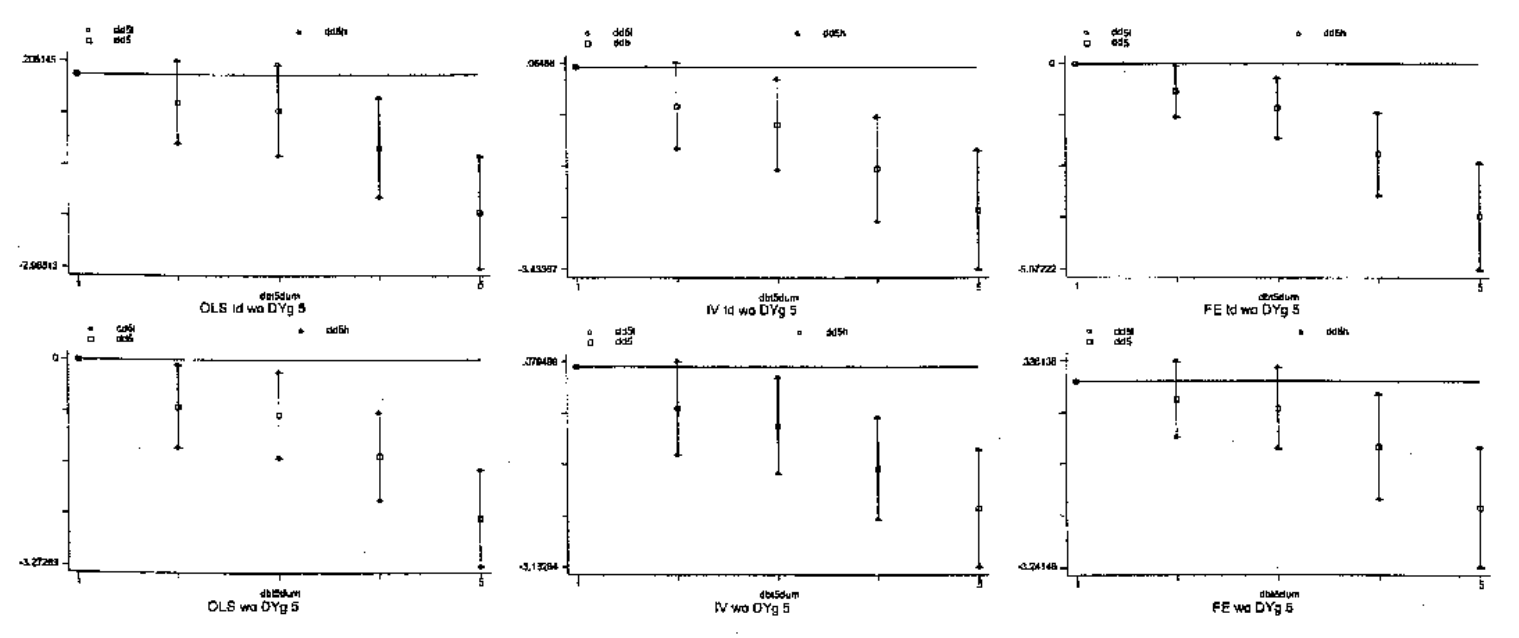

See footnote in Figure 3. 
Figure 6. NPV of Debt to GDP, Without Outliers, OLS, IV, FE

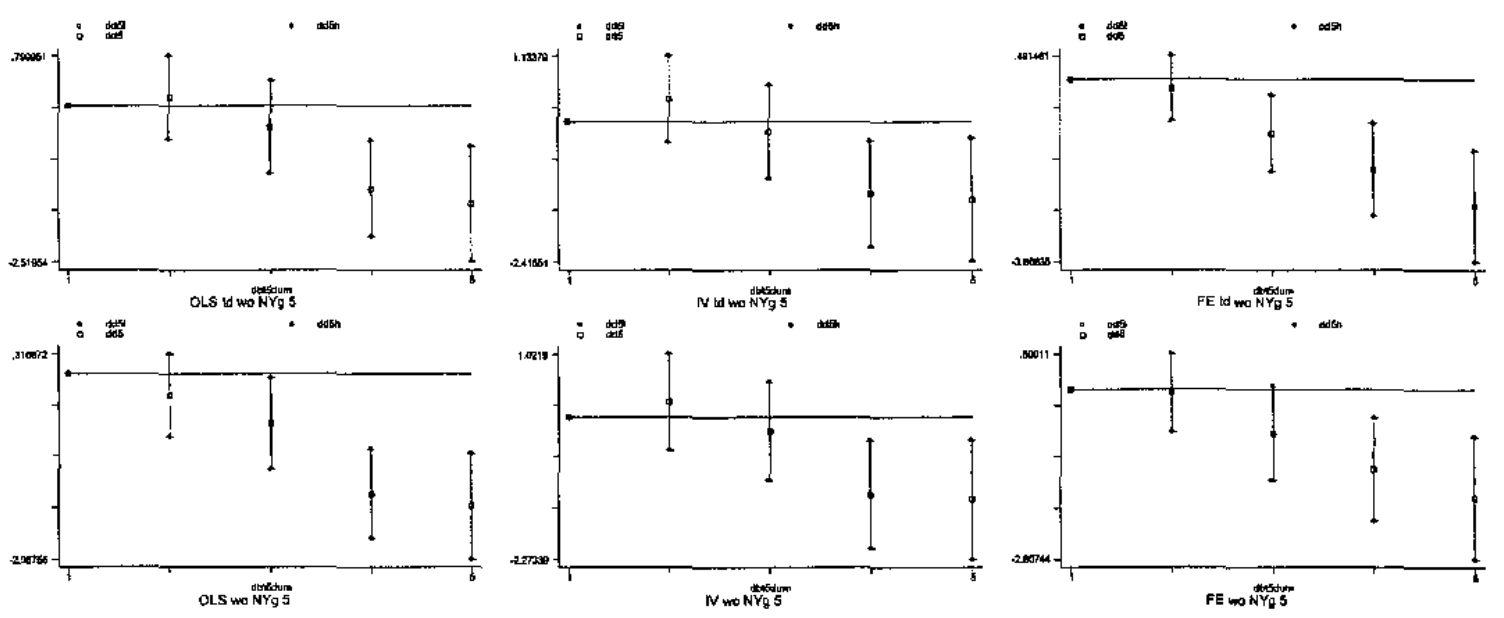

See footnote in Figure 3 
Figure 7. Debt to Exports, Without Outliers and Investment

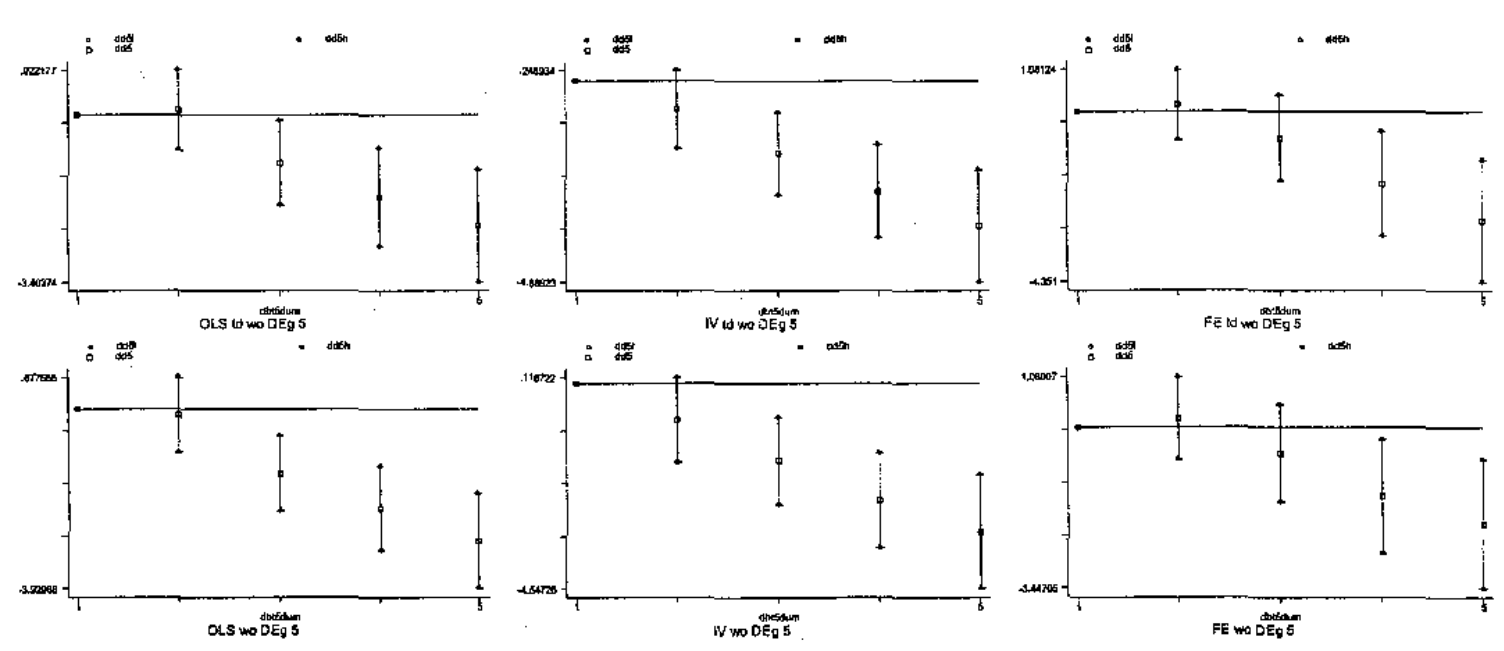

See footnote in Figure 3. 
Figure 8. Debt to GDP, Without Outliers and Investment, OLS, IV, FE

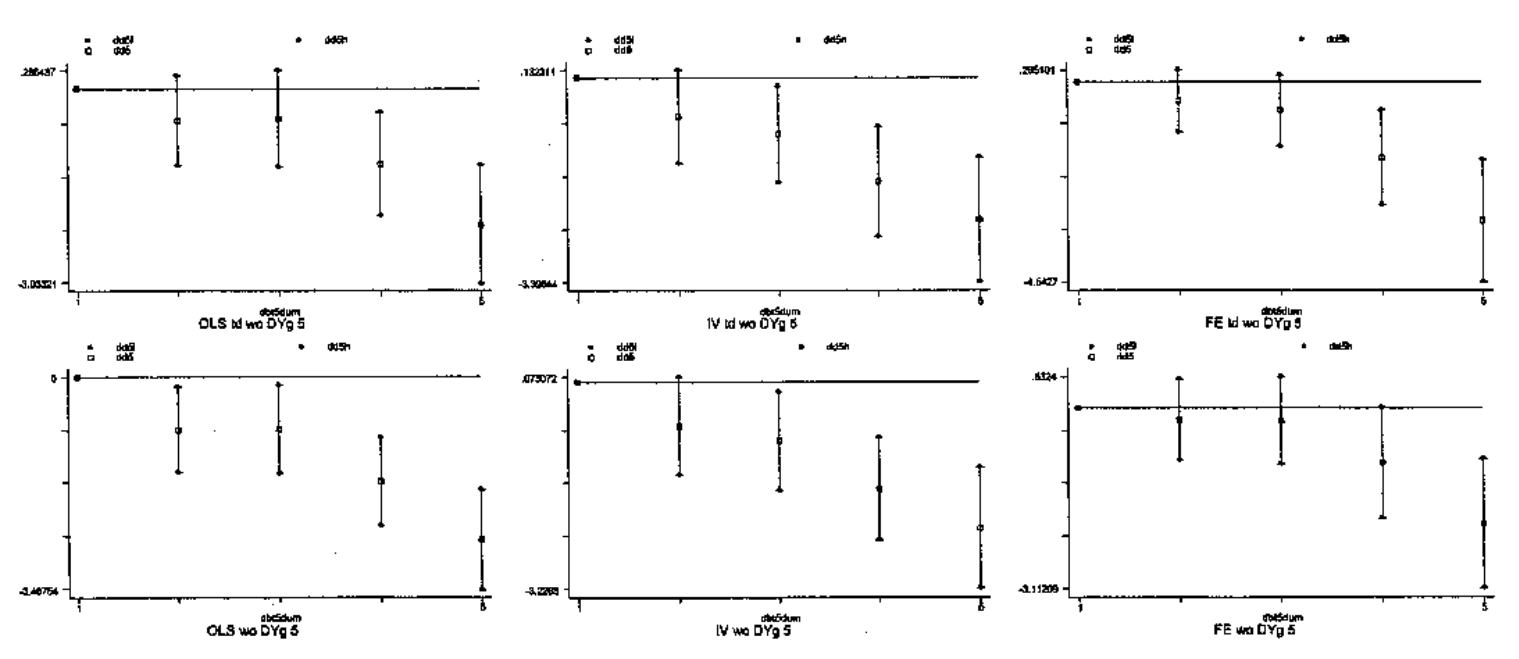

See footnote in Figure 3. 
Figure 9. NPV of Debt to Exports, Without Outliers and Investment, OLS, IV, FE
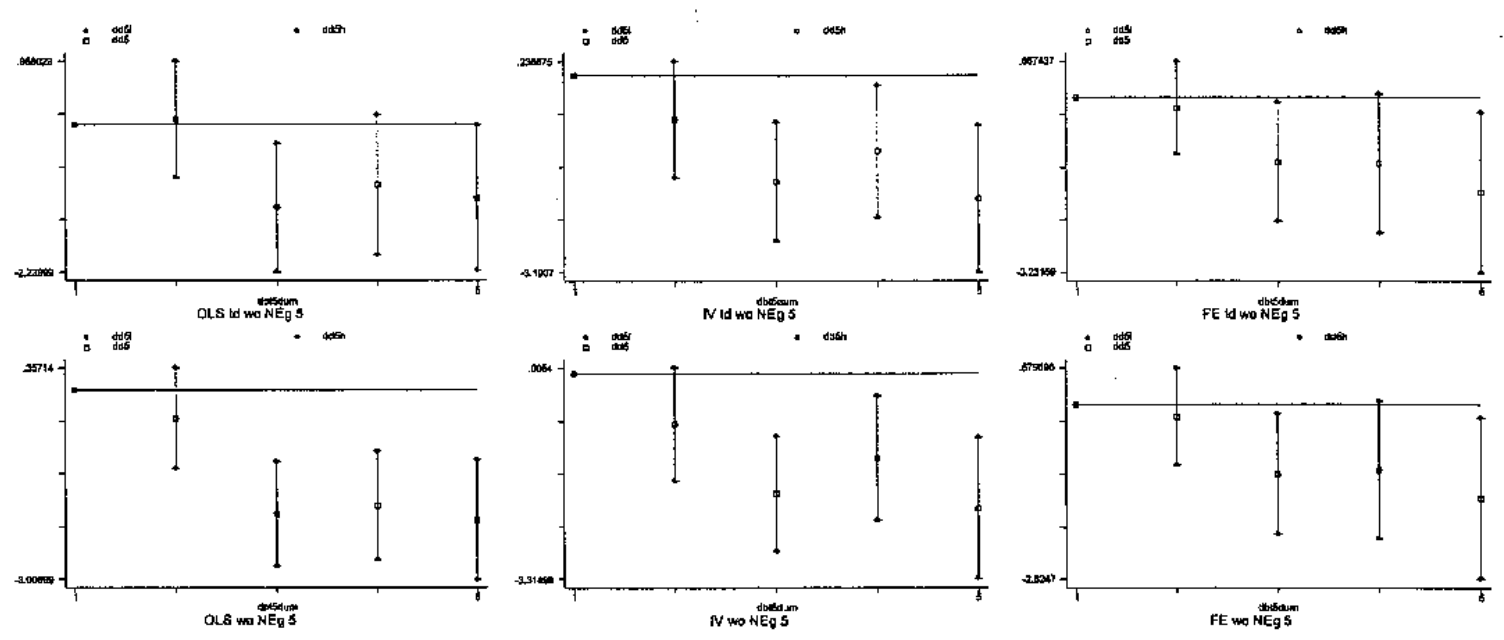

See footnote in Figure 3 
Figure 10. NPV of Debt to GDP, Without Outliers and Investment, OLS, IV, FE

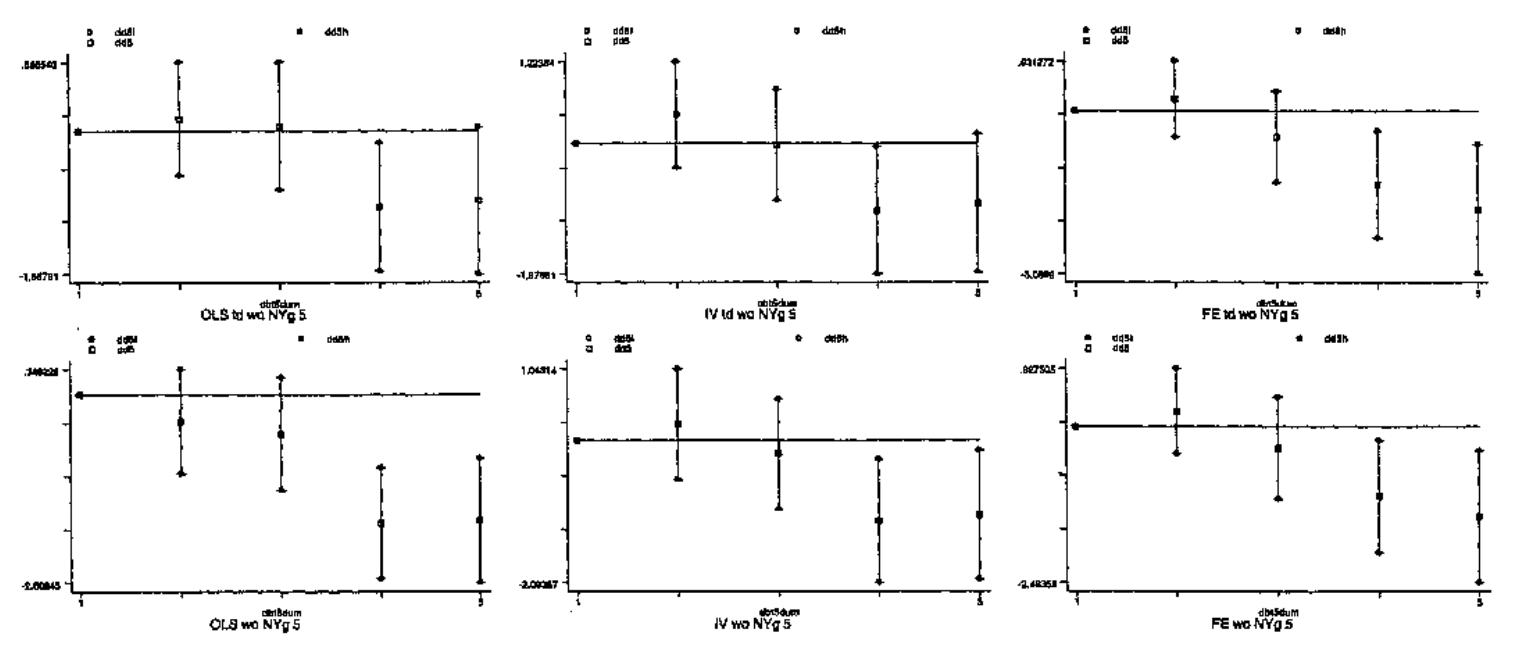

See footnote in Figure 3 
Figure 11. Stylized Shape of the Non linear Relation Between Debt and Growth

\section{Stylized shape of the non-finear relation between debt and growth}

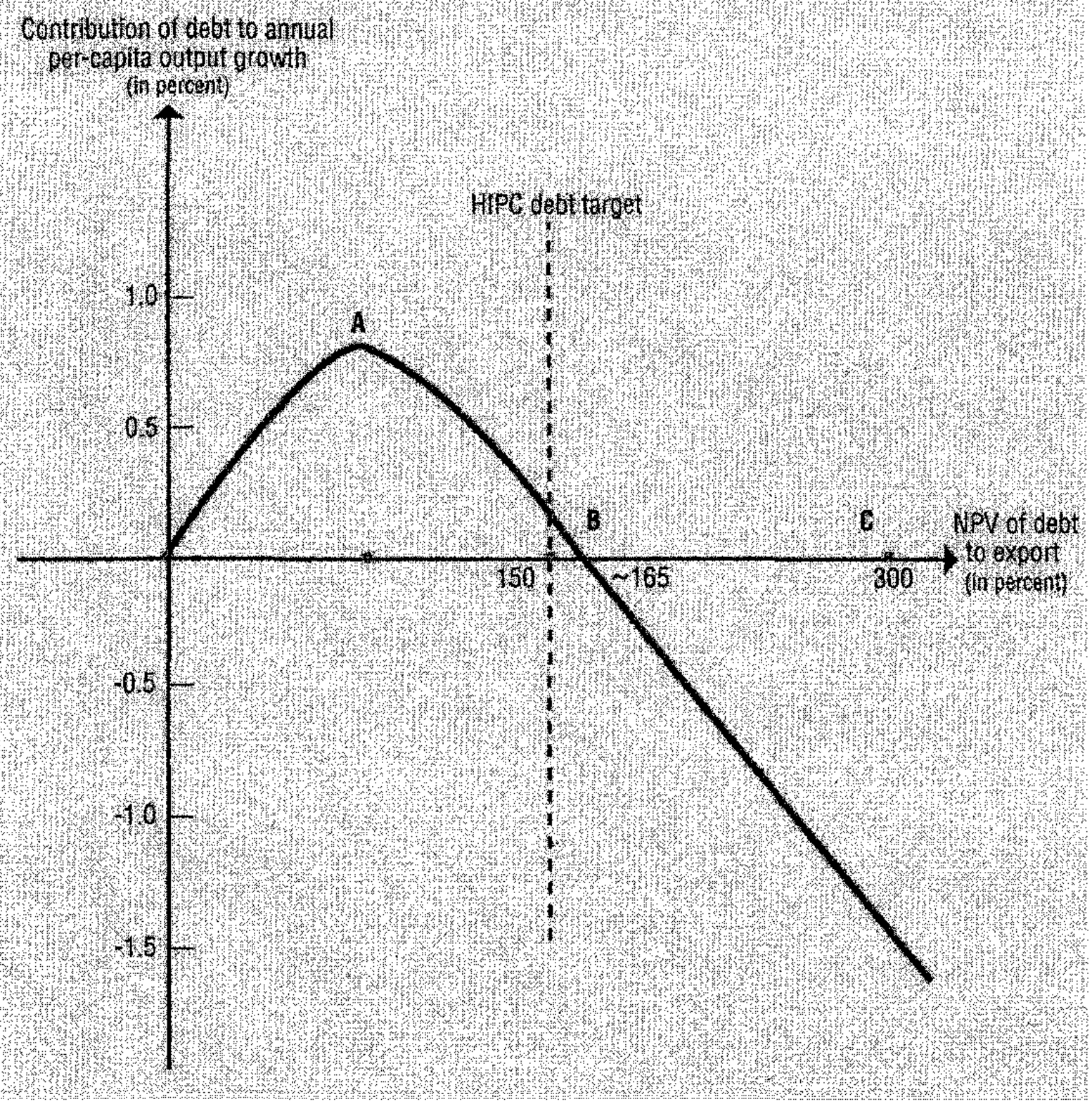




\section{REFERENCES}

Agénor, Pierre-Richard, and Peter J. Montiel (1996). Development Macroeconomics, Princeton University Press, Princeton.

Alesina, Alberto, and Guido Tabellini (1989). "External Debt, Capital Flight and Political Risk," Journal of International Economics, Vol. 27, pp. 199-220.

Barro, Robert J., and Xavier Sala-i-Martin (1995). Economic Growth, McGraw-Hill, Inc., New York.

Barro, Robert J., N. Gregory Mankiw, and Xavier Sala-i-Martin (1995). "Capital Mobility in Neoclassical Models of Growth," The American Economic Review, Vol. 85, pp.103-115.

Blundell, Richard, and Stephen Bond (1998). "Initial Conditions and Moment Restrictions in Dynamic Panel Data Models," Journal of Econometrics, Vol. 87, pp. 115-143.

Calvo, Guillermo A. (1998). "Growth, Debt and Economic Transformation: The Capital Flight Problem," in Coricelli, Fabrizio, Massimo di Matteo, and Frank Hahn (eds.) New Theories in Growth and Development, St. Martin's Press, New York.

Cohen, Daniel (1991), Private Lending to Sovereign States: A Theoretical Autopsy, The MIT Press, Cambridge. , (1992), "Large External Debt and (Slow) Domestic Growth: A Theoretical Analysis," Journal of Economic Dynamics and Control, Vol. 19, pp. 1141-1163. , (1993), "Low Investment and Large LDC Debt in the 1980s," American Economic Review, Vol. 83, pp. 437-449. , (1997), "Growth and External Debt: A New Perspective on the African and Latin American Tragedies," Centre for Economic Policy Research Discussion Paper, No. 1753.

Cohen, Daniel and Jeffrey Sachs, (1986), "Growth and External Debt under Risk of Debt Repudiation," European Economic Review, Vol. 30. pp. 529-550.

Corden, W. Max. (1989), "Debt Relief and Adjustment Incentives," in Frenkel, Jacob A., Michael P. Dooley and Peter Wickham (eds.) Analytical Issues in Debt, International Monetary Fund, Washington DC.

Easterly, William. (2001), The Elusive Quest for Growth. MIT Press, Cambridge, MA. 
Easterly, William, (2001), "Growth Implosions, Debt Explosions, and My Aunt Marilyn: Do Growth Slowdowns Cause Public Debt Crises?' World Bank Policy Research Working Paper, No. 2531.

, and Ross Levine (2001), "It's Not Factor Accumulation: Stylized Facts and Growth Models," Mimeo, World Bank and University of Minnesota. , and Ross Levine (1997), "Africa's Growth Tragedy: Policies and Ethnic Divisions," Quarterly Journal of Economics, Vol. 112, No 4, pp. 1203-50.

Eaton, Jonathan, (1993), "Sovereign Debt: A Primer," World Bank Economic Review, Vol. 7, No. 2, pp. 137-172.

Elbadawi, Ibrahim, Benno Ndulu, and Njuguna Ndung'u (1997), "Debt Overhang and Economic Growth in Sub-Saharan Africa," in Iqbal, Zubair and Ravi Kanbur (eds.) External Finance for Low-Income Countries, IMF Institute, Washington DC.

Fosu, Augustin, (1999), "The External Debt Burden and Economic Growth in the 1980s: Evidence from Sub-Saharan Africa," Canadian Journal of Development Studies, Vol. 20, No 2, pp. 307-318.

Gertler, Mark, and Kenneth Rogoff (1990), "North-South Lending and Endogenous Capital Market Inefficiencies," Journal of Monetary Economics, Vol. 26, pp. 245-266.

Hoeffler, Anke, (1999), "The Augmented Solow Model and the African Growth Debate," mimeo, Centre for the Study of African Economies, University of Oxford, Oxford.

International Development Association and International Monetary Fund, (2001), "The Challenge of Maintaining Long-Term External Debt Sustainability," Washington, D.C.

Islam, Nazrul (1995), "Growth Empirics: A Panel Data Approach," Quarterly Journal of Economics, Vol. 110, No. 4, pp. 1127-70.

Krugman, Paul, (1988), "Financing vs. Forgiving a Debt Overhang," Journal of Development Economics, Vol. 29, pp. 253-268.

Mankiw, N. Gregory, David Romer, and David Weil (1992), "A Contribution to the Empirics of Economic Growth," Quarterly Journal of Economics, Vol. 107, No. 2, pp. 407-437.

Pritchett, Lant, (1996), "Where Has All the Education Gone?" World Bank Policy Research Working Paper, No. 1581.

Sachs, Jeffrey, (1989), "The Debt Overhang of Developing Countries," in Calvo, Guillermo A. and others (eds.) Debt Stabilization and Development: Essay in Memory of Carlos Diaz Alejandro, Basil Blackwell, Oxford. 
Sarel, Michael, (1996), "Nonlinear Effects of Inflation on Economic Growth," International Monetary Fund Staff Papers, Vol. 43, No.1, pp. 199-215.

Servén, Luis, (1997), "Uncertainty, Instability, and Irreversible Investment: Theory, Evidence, and Lessons for Africa," World Bank Policy Research Working Paper, No. 1722.

Tornell, Aaron, and Andres Velasco (1992), "The Tragedy of the Commons and Economic Growth: Why Does Capital Flow from Poor to Rich Countrics?" Journal of Political Economy, Vol. 100, No. 6, pp. 1208-1231. 
